\title{
The State of Artificial Intelligence in Marketing With Directions for Future Research
}

\author{
Jing Chen, Texas A\&M University, Kingsville, USA* \\ Jose Humberto Ablanedo-Rosas, The University of Texas at El Paso, USA \\ (iD) https://orcid.org/0000-0002-3030-8474 \\ Gary L. Frankwick, The University of Texas at El Paso, USA \\ Fernando R. Jiménez Arévalo, The University of Texas at El Paso, USA
}

\begin{abstract}
Today, artificial intelligence (AI) is becoming increasingly important in both industry and academics. To investigate AI in marketing, the authors have used bibliometric study, social network analysis (SNA), main path analysis, and content analysis to examine the top 10 authors, top 20 most cited articles, and top 11 milestone papers from the 628 article sample. Bibliometric study identified leading authors, documents, universities, countries, and sources of these articles. By using SNA, they spotted an academic social network of crucial publications. Moreover, they recognized 11 milestone articles that constitute the main knowledge flow in AI marketing through main path analysis. Finally, they discussed future directions based on the findings. The study is one among a few studies that have used bibliometric analysis methods to analyze and visualize the citation network of the AI-marketing interface.
\end{abstract}

\section{KEYWORDS}

Artificial Intelligence, Bibliometric Analysis, Literature Review, Main Path Analysis, Marketing Research, Social Network Analysis

\section{INTRODUCTION}

Marketing is a complex decision-making discipline that involves not only the commonly known 4Ps (product, price, promotion, and place) but also strategic issues such as new product development (NPD), customer relationship management (CRM), selling strategies, market segmentation, positioning and targeting, international marketing, marketing research, etc. (Rutz \& Watson, 2019). With the everincreasing amount and importance of "big data," now scholars are interested in whether appropriate decision-making technologies can solve marketing problems.

Artificial intelligence (AI), which refers to machines and software that exhibit human intelligence, can provide great opportunities to facilitate decision-making in marketing. The existence of AI could be traced back to 1955 when John McCarthy coined the term Artificial Intelligence. In his work, AI was defined as "making a machine behave in ways that would be called intelligent if a human were so behaving" (McCarthy et al., 1955). Since then, AI definition has evolved as "manifested by machines 
that exhibit aspects of human intelligence" (Huang \& Rust 2018, p. 155). With the tools of machine learning, deep learning, neural networks, and natural language processing, AI could "interpret external data correctly, learn from such data, and exhibit flexible adaptation" (Kaplan \& Haenlein, 2019, p. 17). There are substantial AI-based examples (Kumar et al., 2016, Huang \& Rust, 2017). For instance, when you post a photo on Facebook, it can automatically recognize you and your friends' faces and tag their names; when you are off, Amazon's Alexa and Google-Home work as virtual assistants to take care of your home, set the room temperature, manage your schedules, and control the lights; when you ask Amazon for return, its chatbot serves you all the time.

In this regard, the definition of AI in marketing could be illustrated by those business recognitions. AI can implement simple marketing transactions, such as translating emails or phone calls to automate replies, reading customers' online comments, and smart retailing by recommending products to customers. AI can leverage machine learning tools to analyze large volumes of customer digital footprints, including reviews, video, images, subscriptions, browsing history, webpage activities, and even facial expression data. Those analyses empowered AI to gain a deep understanding of customers' preferences, behaviors, likes/dislikes, trends, etc. AI could engage customers through real-time interaction and customized digital advertising recommendations. This fast movement allows AI to stay actively engaged with customers to influence their decision-making.

Due to the ever-increasing interest and importance of AI applications in our marketing field, a comprehensive review that precisely analyzes the AI-marketing (AIM) interface literature is imperative to properly understand the constantly growing AIM field (Siau \& Yang, 2017). The literature review aims to provide a holistic view and meaningful research questions in AIM studies. Bibliometric study, social network analysis, main path analysis, and content analysis are effective tools used to conduct this systematic literature review.

Bibliometric studies explore a large amount of content in academic journals, including the journal citation information, to identify its leading trend (Bonilla et al., 2015). Journal authors, keywords, affiliations, and citations are also collected and traced in a bibliometric study. Social network analysis is usually followed after a bibliometric study to provide insights about institutions, countries, and keyword collaboration networks. Social network analysis monitors and interprets social ties among social nodes to visualize how the relationships in a group relate to each other and determine the types of relationships that lead to effective outcomes (Stangor, 2015). The main path analysis is based on social network analysis to detect the meaningful and traceable main paths representing the journals in the social network. The importance of path is measured by "counting the number of times a citation link has been traversed if one exhausts the search from a set of starting nodes to another set of ending nodes" (Hummon \& Coreian 1989, p. 50).

The remainder of this paper is organized into the following sections. It starts with section 1 introducing its background and states the contributions we are trying to make: to provide a holistic view and meaningful research questions in AIM studies. Following the introduction, we have conducted a literature review (section 2) about marketing bibliometric studies and artificial intelligence in marketing; we found that there have been a limited number of publications examining AI in marketing. Thus, a systematic bibliometric review of AIM is needed, while a comparative and quantitative analysis of AIM studies will provide more insight for scholars. Section 3 described how we obtained the literature and implemented four methods: bibliometric study, social network analysis, main path analysis, and content analysis to analyze those articles. Section 4 presented the results followed by major findings within the study and pointed out potential future research streams in section 5 . 


\section{LITERATURE REVIEW}

\subsection{Literature Review of Marketing Bibliometric Studies}

Bibliometric analysis has been widely used in literature reviews on a broad range of topics in the business discipline: including marketing, advertising (Kim \& McMillan, 2008), sales management (Johnson, 2006), accounting (Zhong et al., 2016), strategic management (Vogel \& Guttel, 2013), and supply chain management (Asgari et al., 2016), and so on.

\subsection{Literature Review of Artificial Intelligence in Marketing}

Recently, as an application of digital marketing tools, artificial intelligence (AI) has been actively catching people's attention. Generally, AI is relevant to any intellectual task. There are many applications in the business world (Balducci \& Marinova, 2018, Thomaz et al., 2020). Banks use artificial intelligence systems to organize operations, maintain investments in stocks, detect fraud, and manage properties (Fethi \& Pasiouras, 2010). AI tools make individualized pricing easy to achieve through estimating individualized demand and supply curves (Marwala \& Hurwitz, 2017). Using AI tools, marketers can now track customers' digital footprints to predict their general online behaviors and target them with personalized promotions and products (Hennig-Thurau et al., 2015, Matz et al., 2017). Recently, the applications of personality computing AI tools have been used to reduce the cost of advertising campaigns because it adds psychological targeting to traditional behavioral targeting (Celli et al., 2017). AI is still a relatively new research stream, and there is a limited number of publications presenting artificial intelligence applications in marketing. Yang and Siau (2018) published a longitudinal case study exploring whether AI and robots will replace salespeople and marketers. Marinchak et al. (2018) explored new rules of engagement with the advent of AI. They recommended marketers to integrate virtual personal assistants to meet users' actual needs. Mitić (2019) concluded that with the new artificial neural network algorithms, AI applications in marketing would become more personalized to reflect customer needs better. IT companies that run in chatbots, robots, and other AI applications will have tremendous advantages in marketing. André et al. (2018) articulated that although artificial intelligence-based tools can provide customers convenience and efficiency, it also undermines consumers' sense of autonomy. Their papers explored the boundaries within which new technologies may enhance or diminish consumers' perception of control. Kose and Sert (2017) examined how artificial intelligence tools could integrate digital content to upgrade content marketing. Their paper proposed a model to apply AI-based optimization algorithms to content marketing scenarios to maximize success ratios. Jarek and Mazurek (2019) found that AI is widely used in the marketing field, although most use is operational. The uncertainty of the outcomes of AI impedes the diffusion and adoption of AI in the business field. Doğan (2018) developed an AI mobile banking acceptance model. AI was studied in many marketing domains, such as AI in retailing (Grewal et al., 2017), AI in banking (Leone et al., 2021), AI in automotive (Davenport et al., 2020, Vlačić et al., 2021), AI in fashion (Davenport et al., 2020), AI in sales and service (Leminen et al., 2018; Mustak et al., 2021), Cloud service in AI (Živković 2019), AI in manufacturing (Li et al., 2017; Mele et al., 2018), AI ethical issues (Stahl et al., 2021), and AI enhances market performance (Paschen, Pitt, \& Kietzmann 2020). Future research in AI could explore more on the use of AI technology and applications, the role of institutional support, and the importance of data protection and ethics in AI. More details are shown in table 1.

These works of literature provide a good view of the current state of AIM research. Although AI has been a hot topic for a while, AI academic studies are still in an infancy stage. Until now, there have been a limited number of publications examining AI in marketing. Thus, a systematic bibliometric review of AIM is needed; a comparative and quantitative analysis of AIM studies will provide more insight for scholars. 
Table 1. Al research in marketing domains

\begin{tabular}{|c|c|c|c|}
\hline Domains & FINDINGS OF ITS FUNCTIONS & EXAMPLES & STUDIES \\
\hline AI IN RETAILING & $\begin{array}{l}\text { - analyze and process customer } \\
\text { information, } \\
\text { - inform product recommendations, } \\
\text { • provide product physical locations } \\
\text { within a store } \\
\text { - response to simple customer requests }\end{array}$ & $\begin{array}{l}\text { e.g., Virchbox AI } \\
\text { can predict what } \\
\text { customer wants }\end{array}$ & $\begin{array}{l}\text { Grewal, Roggeveen, \& } \\
\text { Nordfält (2017) }\end{array}$ \\
\hline AI IN BANKING & $\begin{array}{l}\bullet \text { prevent fraud } \\
\bullet \text { detect unauthorized use of credit } \\
\text { cards } \\
\bullet \text { customized offers }\end{array}$ & $\begin{array}{l}\text { e.g., Knightscope's } \\
\mathrm{k} 5 \text { is a security } \\
\text { robot with superior } \\
\text { sensing capabilities } \\
\text { to patrol in malls } \\
\text { and bank office }\end{array}$ & Leone et al., (2021) \\
\hline AI IN AUTOMOTIVE & $\begin{array}{l}\text { - observe and analyze speed and } \\
\text { direction of the other cars } \\
\text { - process traffic light and other cars } \\
\text { information to carry out actions } \\
\text { - driverless cars }\end{array}$ & $\begin{array}{l}\text { e.g., Tesla will } \\
\text { impact auto } \\
\text { insurance, taxi } \\
\text { service, and } \\
\text { whether customer } \\
\text { behaviors in car } \\
\text { purchase. }\end{array}$ & $\begin{array}{l}\text { Davenport et al., (2020), } \\
\text { Vlačić et al., (2021) }\end{array}$ \\
\hline AI IN FASHION & $\begin{array}{l}\bullet \text { creative fashion design and product } \\
\text { ideas }\end{array}$ & $\begin{array}{l}\text { e.g., Stitch fix } \\
\text { AI creates a } \\
\text { set of stylish } \\
\text { clothing items for } \\
\text { customers. }\end{array}$ & Davenport et al., (2020) \\
\hline $\begin{array}{l}\text { AI IN SALES AND } \\
\text { SERVICE }\end{array}$ & $\begin{array}{l}\text { - automate part of the sales process } \\
\text { - chatbot answers customer questions } \\
\text { - analyze customer satisfactions to } \\
\text { provide novel services }\end{array}$ & $\begin{array}{l}\text { e.g., Conversica AI } \\
\text { bots interact with } \\
\text { customer service } \\
\text { and sales inquiries. }\end{array}$ & $\begin{array}{l}\text { Leminen et al., (2018); } \\
\text { Mustak et al., (2021) }\end{array}$ \\
\hline $\begin{array}{l}\text { CLOUD SERVICE } \\
\text { IN AI }\end{array}$ & $\begin{array}{l}\text { - cloud service provide technological } \\
\text { platforms to support ai. } \\
\text { • it provides technological lens to } \\
\text { analyze data and facilitates ai self- } \\
\text { learning. }\end{array}$ & $\begin{array}{l}\text { e.g., Amazon web } \\
\text { services (AWS) } \\
\text { enhances amazon } \\
\text { personalize; azure } \\
\text { in microsoft cloud } \\
\text { service is powerful } \\
\text { in supporting } \\
\text { machine and deep } \\
\text { learning. }\end{array}$ & Živković (2019) \\
\hline $\begin{array}{l}\text { AI IN } \\
\text { MANUFACTURING }\end{array}$ & $\begin{array}{l}\text { - intelligent design and creative ideas } \\
\text { - intelligent robot } \\
\text { - intelligent product life cycle } \\
\text { manufacturing technology and platform }\end{array}$ & $\begin{array}{l}\text { e.g., IBM } \\
\text { interactive AI } \\
\text { provides inputs to } \\
\text { facilitate business } \\
\text { process. }\end{array}$ & $\begin{array}{l}\text { Li et al., (2017) } \\
\text { Mele, Spena, \& } \\
\text { Peschiera, } \\
\text { (2018) }\end{array}$ \\
\hline AI ETHICAL ISSUES & $\begin{array}{l}\text { - problems of algorithmic biases } \\
\text { - manipulation of the large data set } \\
\text { required by ai techniques. } \\
\text { - customer worry data privacy }\end{array}$ & $\begin{array}{l}\text { e.g., Amazon } \\
\text { abandoned one AI } \\
\text { tool that rate job } \\
\text { applicants, because } \\
\text { it discriminates } \\
\text { female applicants. }\end{array}$ & Stahl et al., (2021) \\
\hline $\begin{array}{l}\text { AI ENHANCE } \\
\text { MARKET } \\
\text { PERFORMANCE }\end{array}$ & $\begin{array}{l}\text { - better sales performance } \\
\text { - high customer satisfaction and } \\
\text { loyalty } \\
\text { - better customer prediction }\end{array}$ & $\begin{array}{l}\text { e.g., Hyatt hotels } \\
\text { group used AI } \\
\text { increase room } \\
\text { revenue up to } 60 \% \text {. }\end{array}$ & $\begin{array}{l}\text { Paschen, Pitt, \& } \\
\text { Kietzmann, (2020) }\end{array}$ \\
\hline
\end{tabular}




\section{MATERIALS AND METHODS}

The study aims to identify and analyze AI in marketing studies to classify emerging themes and point out future research directions. The unit of measure used in this study was individual articles published with the broad topics of artificial intelligence stream and marketing stream interface. We collect our sample articles by conducting a thorough search using a series of keywords across Web of Science (WOS) database.

Keywords represent the essence of articles, and their choice is critical. To capture as many articles as possible, we have used the following search strings to present AI stream: "artificial intelligence," or "machine learning," or robot), we also used strings: ("marketing," or "new product" or "customer relationship," or "selling," or "market planning," or sale, or "marketing planning," or brand, or "selling capability," or "new product development capability," or "customer relationship management capability," or "marketing planning capability") to capture more marketing activities. The final sample article was generated from (AI streams) AND (marketing streams). The quotation marks mean the exact phrase is searched; the keywords without quotation marks mean the phrases that contain those keywords are searched.

We filtered out articles published before 1982 and non-English because we noticed that AI in marketing had very few publications before 1982. The study only included published articles indexed by the Web of Science (WOS) database. Book reviews, comments to the editor, and similar articles were excluded from the analysis. We also manually excluded the duplicate articles and the articles that are not in a business setting. After ruling out all the duplicates, it generated 628 articles from the years 1982 to 2019. Although this dataset did not cover every AIM article ever published, the rigorous data selection process ensures that the dataset reasonably represents the AI field. We configured all 628 papers into the WOS citation format and fed the data into R software to do the bibliometric analysis. The software systems that are utilized for network analysis and main path analysis are VOSviewer 1.6.5(Appio et al., 2017) and Pajek 5.0.1 (Strozzi et al., 2017). The following flow chart in figure 1 describes the methods in our studies.

\section{RESULTS}

We analyzed the literature review on AIM using a bibliometric study, social network analysis, main path analysis, and content analysis.

\subsection{Bibliometric Result: Basic Statistics}

The 628 articles generated 7951 cited references, which corresponded to an average of 12.66 citations per document. Statistics in table 2 shows that teams of researchers have widely explored artificial intelligence, machine learning, robot, and marketing. The average research team consisted of 3.36 authors per document.

The AI-marketing interface does provide good basic statistical information for us to understand the AIM field. The further step is to explore the link between AIM and performance. Theoretically, AI could be interpreted as a capability that is added to a firm's functional activities. The bibliometric study also showed that the Strategic Management Journal is the top journal and a good resource for finding those references.

Figure 2 shows the annual scientific production of the articles that discussed those topics. In the years from 1982 to 2012, the number of annual productions was below or around twenty-five. Before 1980s, AI research mainly focused on math and logical reasoning problems; because of the considerable technical challenges, we did not see a surge in AI research (Wirth, 2018). The studies on $\mathrm{AI}$ in marketing were underdeveloped. The past decade has witnessed impressive breakthroughs in AI. Interactions between firms and customers are increasingly more customized, generating considerable amounts of digitalized footprints. Thanks to greater computing power and the availability of big data 
Figure 1. Methods

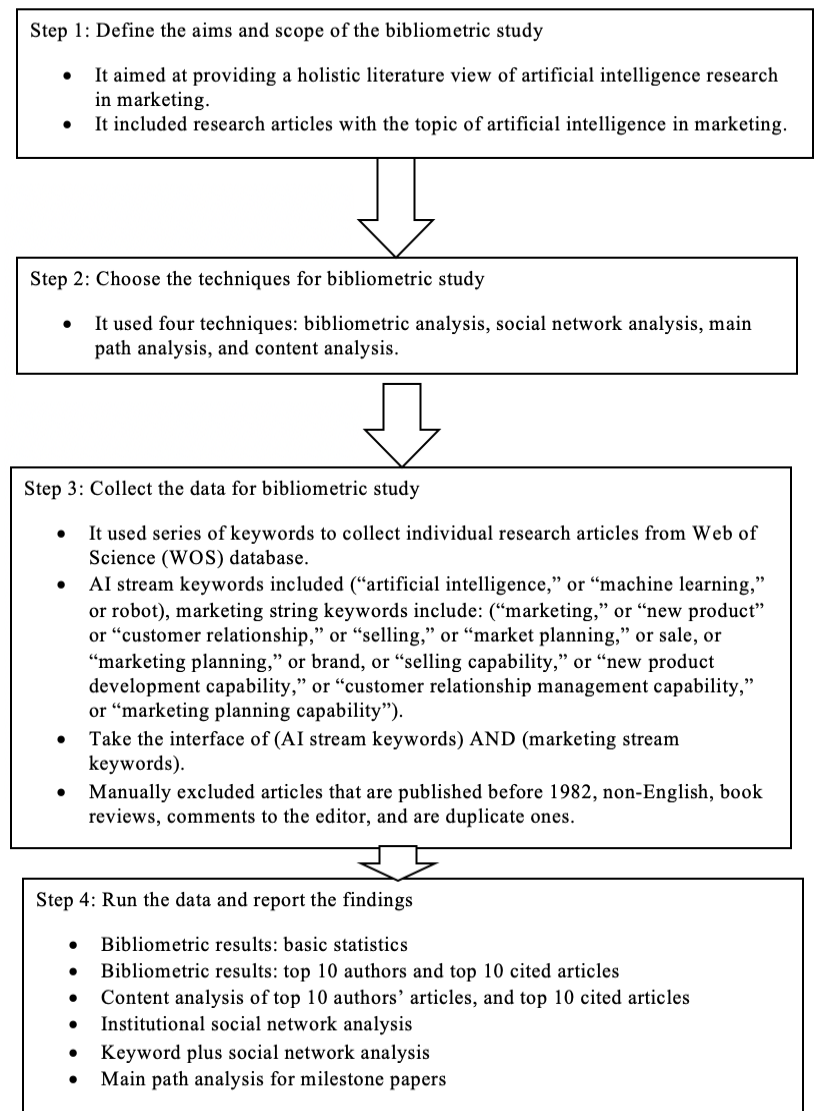

Table 2. Descriptive statistic information

\begin{tabular}{|l|l|}
\hline & AI-marketing interface \\
\hline TOTAL NUMBER OF ARTICLES & 628 \\
\hline PERIOD & $1982-2019$ \\
\hline AVERAGE CITATIONS PER DOCUMENT & 12.66 \\
\hline CO-AUTHORS PER DOCUMENT & 3.36 \\
\hline
\end{tabular}

and more sophisticated algorithms, AI research in marketing is booming. Six years later (in 2018), the number of annual publications surged to 125 , almost five times the sum of the publications from the past 30 years, suggesting that interest in the topic will continue to grow.

\subsection{Bibliometric Results: Leading Authors and Documents}

The top 10 leading authors by the number of documents published are listed in Table 3 . Table 3 also shows the other metrics (such as h-index, g-index, m-index, and total citations) for comparison with the number of publications. Although different metrics show different ranks of the top authors, generally, they provide us with good references about the author's importance in the field. The first 
Figure 2. Annual scientific production of articles on specified topics

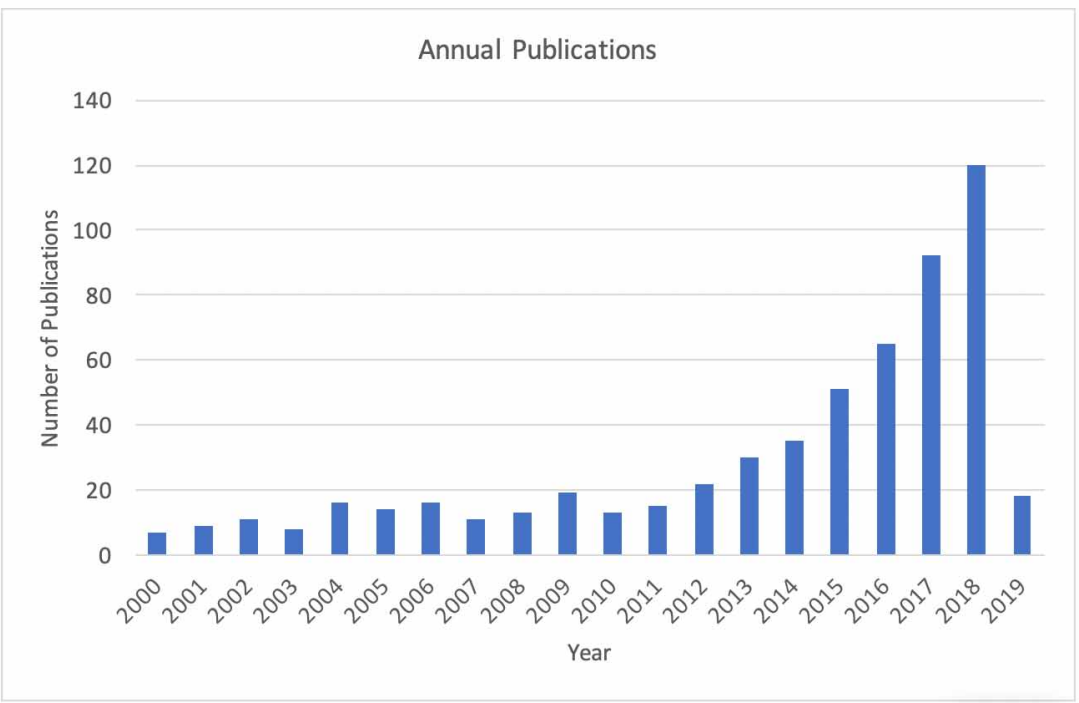

top author is Marko Bohanec, the professor of Engineering and Management at the University of Nova Gorica (Slovenia). The second top author is Mirjana Kljajic Borstnar, a professor of Information Systems at the University of Maribor (Slovenia). After Bohanec and Borstnar, Casillas is a professor of Computer Science and Artificial Intelligence at the University of Granada (Spain), Yoosin Kim is a professor of Management Information Systems at Chungbuk National University (South Korea), and Marko Robnik-Šikonja is a Professor of Computer Science and Informatics at University of

Table 3. Leading publishing authors

\begin{tabular}{|c|c|c|c|c|c|c|c|c|c|}
\hline Author & $H$ & $G$ & $M$ & $T C$ & $T P$ & $\begin{array}{l}\% \text { of } \\
628\end{array}$ & Department & University & Country \\
\hline Marko Bohanec & 2 & 3 & 0.67 & 14 & 5 & 0.79 & Eng \& Mgmt & Uni of Nova Gorica & Slovenia \\
\hline $\begin{array}{l}\text { Mirjana Kljajic } \\
\text { Borstnar }\end{array}$ & 2 & 3 & 0.67 & 14 & 5 & 0.79 & IS & Uni of Maribor & Slovenia \\
\hline Jorge Casillas & 5 & 5 & 0.45 & 134 & 5 & 0.79 & $\mathrm{CS} \& \mathrm{AI}$ & Uni of Granada & Spain \\
\hline Yong-Seog Kim & 3 & 4 & 0.6 & 21 & 5 & 0.79 & Mgmt \& IS & $\begin{array}{l}\text { Chungbuk National } \\
\text { Uni }\end{array}$ & $\begin{array}{l}\text { South } \\
\text { Korea }\end{array}$ \\
\hline $\begin{array}{l}\text { Marko Robnik- } \\
\text { Šikonja }\end{array}$ & 2 & 3 & 0.67 & 14 & 5 & 0.79 & $\begin{array}{l}\text { CS \& } \\
\text { Informatics }\end{array}$ & Uni of Ljubljana & Slovenia \\
\hline Eric Cambria & 3 & 4 & 0.5 & 214 & 4 & 0.63 & CS \& Eng & $\begin{array}{l}\text { Nanyang } \\
\text { Technological Uni }\end{array}$ & Singapore \\
\hline Sooyoung Cho & 3 & 4 & 0.21 & 66 & 4 & 0.63 & $\begin{array}{l}\text { JRNL \& } \\
\text { Comm }\end{array}$ & KyungHee Uni & $\begin{array}{l}\text { South } \\
\text { Korea }\end{array}$ \\
\hline $\begin{array}{l}\text { Francisco J. } \\
\text { Martínez-López }\end{array}$ & 4 & 4 & 0.36 & 62 & 4 & 0.63 & Mktg & Uni of Granada & Spain \\
\hline Dirk Van den Poel & 4 & 4 & 0.25 & 235 & 4 & 0.63 & Mktg & Ghent Uni & Belgium \\
\hline
\end{tabular}

Note: (1) $\mathrm{H}$-index is based on the set of the scientist's most cited papers and the number of citations that they have received in other publications. (2) G-index is calculated based on the distribution of citations received by a given researcher's publications. (3) M-index is the H-index divided by the number of years that a scientist has been active. (4) TC is the total citations. (5) TP is the number of publications. 
Ljubljana (Slovenia). By no surprise, the top 5 scholars in AIM studies are dominated by engineering and computer science scholars.

Table 4 shows the leading author's documents. Due to the length limit, we chose the top 10 articles from these top authors. Please note that the top authors (Marko Bohanec and Mirjana Kljajic Borstnar) collaborate extensively, and their top documents are the same. Therefore, we merge them together.

We have conducted content analysis to explore the main themes in top authors' research. Content analysis uses qualitative and quantitative research techniques to explore and analyze data obtained from written documents. The main goal of content analysis is to enhance researchers' capabilities in identifying new phenomena from exploiting documents. The results often include concepts or categories of topics that summarize the original information investigated. Guided by Elo and Kyngäs (2008), we have used three phases: preparing, organizing, and reporting to conduct our content analysis. In the preparing phase, we aim to identify the common characteristics that can be categorized to describe the information investigated. We manually go through each article to identify the keywords, topic, context, research methods, and findings to classify its themes in the organizing phase. Finally, in the reporting phase, we follow Miah et al. (2017) to present our structured findings.

Our content analysis of the top 10 authors finds that those articles are examining artificial intelligence, machine learning, or robot in marketing topics: such as sales, WOM (word of mouth), Twitter, service, distribution channel, online knowledge sharing service, and consumer behavior modeling. After systematically reviewing their content, keywords, context, methods, and findings, we classified them into three main themes: B2B sales forecasting, machine learning techniques acceptance model, and machine learning knowledge generation and diffusion within the organizational setting.

\section{Theme 1: B2B Sales Forecasting}

The process of $\mathrm{B} 2 \mathrm{~B}$ sales forecasting is a complex decision-making process. In the big data era, the high data collection cost, data computation load, and complicated dataset dimensionalities make effective sales forecasting challenging. To have an effective sales forecast, firms need to identify the correct rank of data features with high impacts (Bohanec et al., 2017). In reality, customers and users keep adding new features to the existing classification models, making it harder to interpret the new features. Bohanec et al. (2017) developed an organizational model that uses a machine learning model and a general explanation method to evaluate the new customer features. Later in 2018, Bohanec et al. (2018) introduced a guideline to determine the sample size needed to estimate the impact of a new feature on sales forecasting. Their results demonstrate that machine learning models have significant advantages in evaluating sellers' actions and outlining the general recommendations in sales strategy (Bohanec et al., 2017).

$\mathrm{B} 2 \mathrm{~B}$ sales forecasting provides substantial evidence that $\mathrm{AI}$ and machine learning techniques could augment a firm's selling capabilities and its subsequent sales performance. Although Bohanec, Borštnar, and Robnik-Šikonja's manuscripts are from a computer science and engineering perspective, the key technical problems they identified and the key machine learning tools and models they built provide significant managerial implications to sales managers and practitioners. This stream of study also enlightens the further exploration of the theory-driven mechanisms behind the curtain. Professional selling involves several steps from a marketing perspective: prospecting, approaching, presenting, overcoming objection, and following up. Researchers can study how AI-based systems or tools are utilized in these steps. Revealing these mechanisms will help managers understand how AI could augment their sales activities and how to configure their organizational resources to strategically optimize this bonus.

\section{Theme 2: Machine Learning Acceptance Model}

Bohanec et al. (2017) also addressed the problem of the low acceptance rate of machine learning models in the business field. The participatory approach of action design research (ADR) was proposed to increase user acceptance of the machine learning model. The proposed framework was 
Table 4. Leading publishing authors' documents and keywords

\begin{tabular}{|c|c|c|c|c|c|}
\hline Articles & Keywords & Classification & Context & Methods & Findings \\
\hline $\begin{array}{l}\text { Bohanec, } M ., \text { Kljajić } \\
\text { Borštnar, } M ., \text { \& } \\
\text { Robnik-Sikonja, M. } \\
(2018) . \text { Number of } \\
\text { Instances for Reliable } \\
\text { Feature Ranking in } \\
\text { a Given Problem. } \\
\text { Business systems } \\
\text { research journal: } \\
\text { international journal } \\
\text { of the Society for } \\
\text { Advancing Business } \\
\text { \& Information } \\
\text { Technology (BIT), } \\
\text { 9(2), 35-44. }\end{array}$ & $\begin{array}{l}\text { machine } \\
\text { learning; } \\
\text { feature ranking; } \\
\text { feature } \\
\text { evaluation }\end{array}$ & $\begin{array}{l}\text { B2B sales } \\
\text { forecasting }\end{array}$ & B2B sales & $\begin{array}{l}\text { Feature evaluation } \\
\text { measure relief and the } \\
\text { bootstrap-based estimation } \\
\text { of confidence intervals for } \\
\text { feature ranks. }\end{array}$ & $\begin{array}{l}\text { A combination of the feature } \\
\text { evaluation measure Relief and } \\
\text { the bootstrap-based estimation } \\
\text { of confidence intervals can be } \\
\text { used to reliably estimate the } \\
\text { impact of a new feature in a } \\
\text { B2B sales problem. }\end{array}$ \\
\hline $\begin{array}{l}\text { Bohanec, M., } \\
\text { Robnik-Šikonja, } \\
\text { M., \& Borštnar, } \\
\text { M. K. (2017). } \\
\text { Organizational } \\
\text { learning supported } \\
\text { by machine learning } \\
\text { models coupled with } \\
\text { general explanation } \\
\text { methods: A Case of } \\
\text { B2B sales forecasting. } \\
\text { Organizacija, 50(3), } \\
217-233 .\end{array}$ & $\begin{array}{l}\text { decision support; } \\
\text { organizational } \\
\text { learning; } \\
\text { machine } \\
\text { learning; } \\
\text { explanations; } \\
\text { B2B sales } \\
\text { forecasting }\end{array}$ & $\begin{array}{l}\text { B2B sales } \\
\text { forecasting; } \\
\text { Machine } \\
\text { learning } \\
\text { acceptance } \\
\text { model }\end{array}$ & B2B sales & $\begin{array}{l}\text { Participatory approach } \\
\text { of action design research } \\
\text { was used to promote } \\
\text { acceptance of the model } \\
\text { among users. ML model } \\
\text { was built following } \\
\text { CRISP-DM methodology } \\
\text { and utilizes R software } \\
\text { environment. }\end{array}$ & $\begin{array}{l}\text { Based on the explanations of } \\
\text { the ML model predictions, } \\
\text { the users' forecasts improved. } \\
\text { Furthermore, when the users } \\
\text { embrace the proposed ML } \\
\text { model and its explanations, } \\
\text { they change their initial } \\
\text { beliefs, make more accurate } \\
\text { B2B sales predictions and } \\
\text { detect other features of the } \\
\text { process, not included in the } \\
\text { ML model. }\end{array}$ \\
\hline $\begin{array}{l}\text { Bohanec, } M ., \\
\text { Borštnar, M. K., \& } \\
\text { Robnik-Šikonja, M. } \\
\text { (2017). Explaining } \\
\text { machine learning } \\
\text { models in sales } \\
\text { predictions. Expert } \\
\text { Systems with } \\
\text { Applications, } 71, \\
\text { 416-428. }\end{array}$ & $\begin{array}{l}\text { Machine } \\
\text { learning; } \\
\text { Prediction } \\
\text { explanation; } \\
\text { Intelligent } \\
\text { system; } \\
\text { Black-box } \\
\text { models; } \\
\text { B2B Sales } \\
\text { forecasting }\end{array}$ & $\begin{array}{l}\text { B2B sales } \\
\text { forecasting }\end{array}$ & B2B sales & $\begin{array}{l}\text { Uniform explanations are } \\
\text { generated on the level of } \\
\text { model/individual instance } \\
\text { and support what-if } \\
\text { analysis. }\end{array}$ & $\begin{array}{l}\text { The presented method is } \\
\text { able to evaluate sellers' } \\
\text { actions and to outline general } \\
\text { recommendations in sales } \\
\text { strategy }\end{array}$ \\
\hline $\begin{array}{l}\text { Bohanec, M., Kljajić } \\
\text { Borštnar, M., \& } \\
\text { Robnik-Šikonja, M. } \\
\text { (2017). Estimation of } \\
\text { minimum sample size } \\
\text { for identification of } \\
\text { the most important } \\
\text { features: a case study } \\
\text { providing a qualitative } \\
\text { B2B sales data set. } \\
\text { Croatian Operational } \\
\text { Research Review, } \\
\text { 8(2), 515-524. }\end{array}$ & $\begin{array}{l}\text { data set } \\
\text { reduction; } \\
\text { B2B sales } \\
\text { forecasting; } \\
\text { machine } \\
\text { learning; } \\
\text { sample size }\end{array}$ & $\begin{array}{l}\text { B2B sales } \\
\text { forecasting }\end{array}$ & B2B sales & $\begin{array}{l}\text { Machine learning } \\
\text { techniques }\end{array}$ & $\begin{array}{l}\text { A relatively small instance } \\
\text { subset is sufficient for } \\
\text { identifying the most important } \\
\text { features when rank is not } \\
\text { important. }\end{array}$ \\
\hline $\begin{array}{l}\text { Bohanec, M., } \\
\text { Robnik-Šikonja, M., \& } \\
\text { Kljajić Borštnar, } M . \\
\text { (2017). Decision- } \\
\text { making framework } \\
\text { with double-loop } \\
\text { learning through } \\
\text { interpretable black- } \\
\text { box machine learning } \\
\text { models. Industrial } \\
\text { Management \& Data } \\
\text { Systems, 117(7), 1389- } \\
\text { 1406. }\end{array}$ & $\begin{array}{l}\text { Machine } \\
\text { learning, } \\
\text { Double-loop } \\
\text { learning, } \\
\text { B2B sales } \\
\text { forecasting, } \\
\text { Explanation } \\
\text { of black-box } \\
\text { models }\end{array}$ & $\begin{array}{l}\text { B2B sales } \\
\text { forecasting; } \\
\text { Machine } \\
\text { learning } \\
\text { acceptance } \\
\text { model }\end{array}$ & B2B sales & $\begin{array}{l}\text { Participatory approach } \\
\text { of action design research } \\
\text { (ADR) }\end{array}$ & $\begin{array}{l}\text { The provided ML model } \\
\text { explanations efficiently } \\
\text { support business decision- } \\
\text { makers, reduce forecasting } \\
\text { error for new sales } \\
\text { opportunities, and facilitate } \\
\text { discussion about the context of } \\
\text { opportunities in the sales team. }\end{array}$ \\
\hline
\end{tabular}


Table 4. Continued

\begin{tabular}{|c|c|c|c|c|c|}
\hline Articles & Keywords & Classification & Context & Methods & Findings \\
\hline $\begin{array}{l}\text { Martínez-López, F. } \\
\text { J., \& Casillas, J. } \\
\text { (2013). Artificial } \\
\text { intelligence-based } \\
\text { systems applied in } \\
\text { industrial marketing: } \\
\text { An historical } \\
\text { overview, current } \\
\text { and future insights. } \\
\text { Industrial Marketing } \\
\text { Management, 42(4), } \\
\text { 489-495. }\end{array}$ & $\begin{array}{l}\text { Intelligent } \\
\text { systems; } \\
\text { Marketing } \\
\text { intelligent } \\
\text { systems; } \\
\text { Industrial } \\
\text { marketing; } \\
\text { Literature } \\
\text { review; } \\
\text { Insights }\end{array}$ & $\begin{array}{l}\text { Knowledge } \\
\text { generation and } \\
\text { diffusion }\end{array}$ & $\begin{array}{l}\text { Industrial } \\
\text { marketing }\end{array}$ & Literature review & $\begin{array}{l}\text { They carry out a historical } \\
\text { literature review of artificial } \\
\text { intelligence-based systems } \\
\text { applied to marketing, covering } \\
\text { a time period of several } \\
\text { decades (from the } 1970 \text { s to } \\
\text { the present day) with a special } \\
\text { focus on applications to } \\
\text { industrial marketing. }\end{array}$ \\
\hline $\begin{array}{l}\text { Orriols-Puig, A., } \\
\text { Martínez-López, F. J., } \\
\text { Casillas, J., \& Lee, } N . \\
\text { (2013). Unsupervised } \\
\text { KDD to creatively } \\
\text { support managers' } \\
\text { decision making with } \\
\text { fuzzy association } \\
\text { rules: A distribution } \\
\text { channel application. } \\
\text { Industrial Marketing } \\
\text { Management, 42(4), } \\
\text { 532-543. }\end{array}$ & $\begin{array}{l}\text { Intelligent } \\
\text { systems; } \\
\text { KDD; } \\
\text { Unsupervised } \\
\text { learning; } \\
\text { Management } \\
\text { support; Genetic } \\
\text { fuzzy systems }\end{array}$ & $\begin{array}{l}\text { Knowledge } \\
\text { generation and } \\
\text { diffusion }\end{array}$ & $\begin{array}{l}\text { Distribution } \\
\text { channel }\end{array}$ & $\begin{array}{l}\text { A novel intelligent } \\
\text { system that incorporates } \\
\text { fuzzy logic and genetic } \\
\text { algorithms to operate in an } \\
\text { unsupervised manner. }\end{array}$ & $\begin{array}{l}\text { The method has significant } \\
\text { potential to improve the } \\
\text { analysis of marketing and } \\
\text { business databases in practice, } \\
\text { especially in non-programmed } \\
\text { decisional scenarios, as well as } \\
\text { to assist scholarly researchers } \\
\text { in their exploratory analysis. }\end{array}$ \\
\hline $\begin{array}{l}\text { Martínez-López, F. J., } \\
\text { \& Casillas, J. (2009). } \\
\text { Marketing Intelligent } \\
\text { Systems for consumer } \\
\text { behaviour modelling } \\
\text { by a descriptive } \\
\text { induction approach } \\
\text { based on Genetic } \\
\text { Fuzzy Systems. } \\
\text { Industrial Marketing } \\
\text { Management, 38(7), } \\
\text { 714-731. }\end{array}$ & $\begin{array}{l}\text { Marketing } \\
\text { modelling; } \\
\text { Management } \\
\text { support; } \\
\text { Analytical } \\
\text { method; } \\
\text { Knowledge } \\
\text { discovery; } \\
\text { Genetic Fuzzy } \\
\text { Systems; } \\
\text { Methodology }\end{array}$ & $\begin{array}{l}\text { Knowledge } \\
\text { generation and } \\
\text { diffusion }\end{array}$ & $\begin{array}{l}\text { Consumer } \\
\text { behavior setting }\end{array}$ & $\begin{array}{l}\text { Genetic Fuzzy Systems, } \\
\text { a specific hybridization } \\
\text { of artificial intelligence } \\
\text { methods. }\end{array}$ & $\begin{array}{l}\text { The valuation of its } \\
\text { performance and utility is very } \\
\text { positive in consumer behavior } \\
\text { modelling. }\end{array}$ \\
\hline $\begin{array}{l}\text { Sánchez, L., Couso, } \\
\text { I., \& Casillas, J. } \\
\text { (2009). Genetic } \\
\text { learning of fuzzy rules } \\
\text { based on low quality } \\
\text { data. Fuzzy Sets and } \\
\text { Systems, 160(17), } \\
\text { 2524-2552. }\end{array}$ & $\begin{array}{l}\text { Genetic fuzzy } \\
\text { systems; Fuzzy } \\
\text { rule-based } \\
\text { systems; Vague } \\
\text { data }\end{array}$ & $\begin{array}{l}\text { Knowledge } \\
\text { generation and } \\
\text { diffusion }\end{array}$ & Marketing & $\begin{array}{l}\text { Genetic fuzzy systems } \\
\text { (GFS) }\end{array}$ & $\begin{array}{l}\text { The techniques proposed } \\
\text { here are shown to improve } \\
\text { the generalization properties } \\
\text { of another knowledge base } \\
\text { obtained from crisp training } \\
\text { data. }\end{array}$ \\
\hline $\begin{array}{l}\text { Casillas, J., \& } \\
\text { Martinez-López, F. } \\
\text { J. (2009). Mining } \\
\text { uncertain data with } \\
\text { multi-objective genetic } \\
\text { fuzzy systems to be } \\
\text { applied in consumer } \\
\text { behavior modelling. } \\
\text { Expert Systems with } \\
\text { Applications, 36(2), } \\
\text { 1645-1659. }\end{array}$ & $\begin{array}{l}\text { Consumer } \\
\text { behavior; Fuzzy } \\
\text { logic; Genetic } \\
\text { algorithms; } \\
\text { Knowledge } \\
\text { extraction; } \\
\text { Machine } \\
\text { learning; } \\
\text { Marketing }\end{array}$ & $\begin{array}{l}\text { Knowledge } \\
\text { generation and } \\
\text { diffusion }\end{array}$ & $\begin{array}{l}\text { Consumer } \\
\text { behavior setting }\end{array}$ & $\begin{array}{l}\text { A complete methodology } \\
\text { that considers the different } \\
\text { stages of knowledge } \\
\text { discovery: data collection, } \\
\text { data mining, and } \\
\text { knowledge interpretation } \\
\text { dynamically. }\end{array}$ & $\begin{array}{l}\text { It is more effective in } \\
\text { modeling consumer behaviors. }\end{array}$ \\
\hline
\end{tabular}


demonstrated with a data mining methodology in a B2B sales forecasting context. The new machine learning techniques helped business decision-makers reduce forecasting errors and to find new sales opportunities.

The machine learning acceptance model is a good starting point to facilitate AI acceptance model development. An early survey shows that most marketing managers say that they can foresee the benefits of AI; however, only $10 \%$ of the surveyed managers are currently using them. Although $\mathrm{AI}$ is promising, it is still at the infancy stage, and it is reasonable to predict that marketers are not confident using AI. From an engineering perspective, Bohanec et al. (2017) studied the factors that impact machine learning acceptance. The results are appealing and exciting. They encourage us to think outside of the box to explore other organizational factors that impact AI acceptance. The technology-organization-environment (TOE) framework (Tornatzky \& Fleischer, 1990), institutional theory (Scott, 1987), and the resource-based view of the firm (Wernerfelt, 1984) have accumulated a rich stream of studies examining disruptive technology acceptance. They provide sound theoretical foundations to employ the AI acceptance model.

\section{Theme 3: Machine Learning Knowledge Generation and Diffusion}

Currently, market-oriented firms find it challenging to leverage the right data to make correct decisions. New technological methods (e.g., machine learning techniques and AI) enhance a firm's ability to exploit data and to generate appropriate knowledge (Orriols-Puig et al., 2013; MartínezLópez \& Casillas, 2009; Sánchez et al., 2009; Casillas \& Martínez-López, 2009). Theoretically, knowledge is the mechanism that links AI tools and firm performance, but how the new technologies are used to generate this knowledge and what kind of marketing activities can implement it remains unknown. Martínez-López and Casillas (2013) systematically reviewed how AI-based systems are used to segment business markets, manage customer relationships, facilitate organizational buying processes, manage business intelligence and knowledge, manage personal selling, and improve service management in the business market. This framework provides a good theoretical reference for understanding how AI-based systems and machine learning techniques could be used in various marketing activities and strategies. From a marketing perspective, knowledge is generated and diffused through marketing activities. Innovation diffusion theory, resource-based views, and technology acceptance models are rooted in knowledge. Knowledge is the resource that facilitates all procedures and steps. Knowledge generation and diffusion perspectives align with the dynamic capability theory (Teece et al. 1997). The combination of both theories helps to articulate the theoretical mechanisms that connect AI-based tools and marketing performance.

\subsection{Bibliometric Results: Most Cited Papers}

The top twenty most cited papers are shown in Table 5. We also used three phases: preparing, organizing, and reporting to conduct a content analysis for tope twenty cited papers (Elo \& Kyngäs, 2008). After identifying the common characteristics that can be categorized to describe the information investigated, we manually go through each article to recognize the keywords, topic, context, research methods, and findings to generate its themes. Finally, we follow Miah et al. (2017) to present our structured findings. As the table shows, thirteen out of the twenty papers are from marketing-related journals or topics. These most cited papers guide us toward the most researchable areas in AIM. Specifically, the most cited papers mentioned could be categorized into five themes: effective selling, customer relationship management (CRM), new product development (NPD), advertising and promotion, and pricing.

\section{Theme 1: Effective Selling:}

Effective selling, especially sales forecasting and prediction, plays significant roles in AIM studies (as shown in leading authors' documents, e.g., Cui \& Curry, 2005; Evgeniou et al., 2007). One impressive 
Table 5. Most Cited papers

\begin{tabular}{|c|c|c|c|c|c|c|}
\hline Document & Keywords & Classification & Context & $L C$ & Methods & Findings \\
\hline $\begin{array}{l}\text { Cui, D., \& Curry, D. (2005). } \\
\text { Prediction in marketing using } \\
\text { the support vector machine. } \\
\text { Marketing Science, 24(4), } \\
595-615 .\end{array}$ & $\begin{array}{l}\text { automated modeling; } \\
\text { choice models; } \\
\text { kernel transformations; } \\
\text { multinomial logit model; } \\
\text { predictive } \\
\text { models; support vector } \\
\text { machine }\end{array}$ & $\begin{array}{l}\text { Effective selling; } \\
\text { pricing }\end{array}$ & $\begin{array}{l}\text { Pure } \\
\text { mathematical } \\
\text { modelling }\end{array}$ & 8 & $\begin{array}{l}\text { Support vector } \\
\text { machine }\end{array}$ & $\begin{array}{l}\text { It identifies and } \\
\text { empirically proves } \\
\text { that the support vector } \\
\text { machine has a better } \\
\text { prediction than other } \\
\text { traditional methods in } \\
\text { marketing. }\end{array}$ \\
\hline $\begin{array}{l}\text { Rui, H., Liu, Y., \& Whinston, } \\
\text { A. (2013). Whose and what } \\
\text { chatter matters? The effect } \\
\text { of tweets on movie sales. } \\
\text { Decision Support Systems, } \\
\text { 55(4), 863-870. }\end{array}$ & $\begin{array}{l}\text { Twitter; } \\
\text { Social broadcasting } \\
\text { networks; Social media; } \\
\text { Word-of-mouth; Movie } \\
\text { sales; Dynamic panel data }\end{array}$ & CRM & $\begin{array}{l}\text { Tweets on } \\
\text { movies }\end{array}$ & 7 & $\begin{array}{l}\text { Machine } \\
\text { learning } \\
\text { algorithm }\end{array}$ & $\begin{array}{l}\text { Twitter WOM has a } \\
\text { significant effect on } \\
\text { product sales. }\end{array}$ \\
\hline $\begin{array}{l}\text { Cheung, K. W., Kwok, J. } \\
\text { T., Law, M. H., \& Tsui, } \\
\text { K. C. (2003). Mining } \\
\text { customer product ratings } \\
\text { for personalized marketing. } \\
\text { Decision Support Systems, } \\
\text { 35(2), 231-243. }\end{array}$ & $\begin{array}{l}\text { Recommender systems; } \\
\text { Personalized marketing; } \\
\text { Support vector machine; } \\
\text { Latent class model }\end{array}$ & $\begin{array}{l}\text { Effective } \\
\text { selling; CRM; } \\
\text { advertising and } \\
\text { promotion }\end{array}$ & $\begin{array}{l}\text { Movie } \\
\text { recommendations }\end{array}$ & 6 & $\begin{array}{l}\text { Recommender } \\
\text { systems; } \\
\text { Support vector } \\
\text { machine; Latent } \\
\text { class model }\end{array}$ & $\begin{array}{l}\text { It studied support vector } \\
\text { machine and the latent } \\
\text { class model in mining } \\
\text { customer product } \\
\text { ratings for personalized } \\
\text { marketing. }\end{array}$ \\
\hline $\begin{array}{l}\text { Myslín, M., Zhu, S. H., } \\
\text { Chapman, W., \& Conway, } \\
\text { M. (2013). Using Twitter to } \\
\text { examine smoking behavior } \\
\text { and perceptions of emerging } \\
\text { tobacco products. Journal } \\
\text { of medical Internet research, } \\
\text { 15(8). }\end{array}$ & $\begin{array}{l}\text { Social media, twitter } \\
\text { messaging, smoking, } \\
\text { natural language } \\
\text { processing }\end{array}$ & NPD; CRM & $\begin{array}{l}\text { Tweets about } \\
\text { smoking behavior }\end{array}$ & 6 & $\begin{array}{l}\text { Content and } \\
\text { sentiment } \\
\text { analysis }\end{array}$ & $\begin{array}{l}\text { Sentiment analysis } \\
\text { and machine learning } \\
\text { classifiers are used to } \\
\text { analyze tobacco-related } \\
\text { tweets. }\end{array}$ \\
\hline $\begin{array}{l}\text { Ghose, A., Ipeirotis, } P . G ., \\
\& \text { Li, B. (2012). Designing } \\
\text { ranking systems for hotels } \\
\text { on travel search engines } \\
\text { by mining user-generated } \\
\text { and crowdsourced content. } \\
\text { Marketing Science, } 31(3), \\
493-520 .\end{array}$ & $\begin{array}{l}\text { User-generated content; } \\
\text { social media; search } \\
\text { engines; hotels; ranking } \\
\text { system; structural } \\
\text { models; text mining; } \\
\text { crowdsourcing }\end{array}$ & $\begin{array}{l}\text { NPD; CRM; } \\
\text { pricing }\end{array}$ & $\begin{array}{l}\text { Hotel } \\
\text { reservations }\end{array}$ & 5 & $\begin{array}{l}\text { Text mining, } \\
\text { image } \\
\text { classification, } \\
\text { social } \\
\text { geotagging, } \\
\text { human } \\
\text { annotations, and } \\
\text { geomapping }\end{array}$ & $\begin{array}{l}\text { Social media techniques } \\
\text { can be incorporated into } \\
\text { a demand estimation } \\
\text { model to obtain an } \\
\text { effective product search } \\
\text { ranking system. }\end{array}$ \\
\hline $\begin{array}{l}\text { Chang, } P . \text { C., Wang, } Y . \\
\text { W., \& Tsai, C. Y. (2005). } \\
\text { Evolving neural network for } \\
\text { printed circuit board sales } \\
\text { forecasting. Expert Systems } \\
\text { with Applications, 29(1), } \\
\text { 83-92. }\end{array}$ & $\begin{array}{l}\text { Sales forecasting; Printed } \\
\text { circuit board; Genetic } \\
\text { algorithm; Neural network }\end{array}$ & Effective selling & $\begin{array}{l}\text { Printed circuit } \\
\text { board industry }\end{array}$ & 4 & $\begin{array}{l}\text { Evolving Neural } \\
\text { Networks } \\
(\text { ENN) } \\
\text { forecasting } \\
\text { model }\end{array}$ & $\begin{array}{l}\text { Evolving neural networks } \\
\text { is used for effective sales } \\
\text { forecasting. }\end{array}$ \\
\hline $\begin{array}{l}\text { Cui, G., Wong, M. L., \& } \\
\text { Lui, H. K. (2006). Machine } \\
\text { learning for direct marketing } \\
\text { response models: Bayesian } \\
\text { networks with evolutionary } \\
\text { programming. Management } \\
\text { Science, 52(4), 597-612. }\end{array}$ & $\begin{array}{l}\text { Direct marketing; Bayesian } \\
\text { networks; evolutionary } \\
\text { programming; machine } \\
\text { learning; data mining }\end{array}$ & CRM; pricing & $\begin{array}{l}\text { Direct } \\
\text { marketing }\end{array}$ & 4 & $\begin{array}{l}\text { Bayesian } \\
\text { networks }\end{array}$ & $\begin{array}{l}\text { This study finds Bayesian } \\
\text { networks have significant } \\
\text { advantages and accuracy } \\
\text { in predicting direct } \\
\text { marketing results. }\end{array}$ \\
\hline $\begin{array}{l}\text { Evgeniou, T., Pontil, M., \& } \\
\text { Toubia, O. (2007). A convex } \\
\text { optimization approach } \\
\text { to modeling consumer } \\
\text { heterogeneity in conjoint } \\
\text { estimation. Marketing } \\
\text { Science, } 26(6), 805-818 .\end{array}$ & $\begin{array}{l}\text { Bayesian analysis; data } \\
\text { mining; econometric } \\
\text { models; estimation } \\
\text { and other statistical } \\
\text { techniques; hierarchical } \\
\text { Bayes analysis; marketing } \\
\text { research; regression and } \\
\text { other statistical techniques }\end{array}$ & $\begin{array}{l}\text { Effective selling; } \\
\text { CRM }\end{array}$ & $\begin{array}{l}\text { Pure } \\
\text { mathematical } \\
\text { modelling }\end{array}$ & 4 & $\begin{array}{l}\text { convex } \\
\text { optimization } \\
\text { and statistical } \\
\text { machine } \\
\text { learning }\end{array}$ & $\begin{array}{l}\text { This study finds that } \\
\text { statistical machine } \\
\text { learning provides a new } \\
\text { alternative in modeling } \\
\text { consumer heterogeneity } \\
\text { in conjoint estimation. }\end{array}$ \\
\hline $\begin{array}{l}\text { Abernethy, J., Evgeniou, } \\
\text { T., Toubia, O., \& Vert, } \\
\text { J. P. (2008). Eliciting } \\
\text { consumer preferences using } \\
\text { robust adaptive choice } \\
\text { questionnaires. IEEE } \\
\text { Transactions on Knowledge } \\
\text { and Data Engineering, 20(2), } \\
\text { 145-155. }\end{array}$ & $\begin{array}{l}\text { Marketing, machine } \\
\text { learning, statistical, } \\
\text { interactive systems, } \\
\text { personalization, } \\
\text { knowledge acquisition. }\end{array}$ & NPD & $\begin{array}{l}\text { New product } \\
\text { development } \\
\text { marketing } \\
\text { context }\end{array}$ & 4 & $\begin{array}{l}\text { Regularization } \\
\text { Networks } \\
\text { and adaptive } \\
\text { questionnaire }\end{array}$ & $\begin{array}{l}\text { This study finds that } \\
\text { machine learning } \\
\text { has great potential } \\
\text { in marketing } \\
\text { personalization and } \\
\text { knowledge acquisition. }\end{array}$ \\
\hline
\end{tabular}


Table 5. Continued

\begin{tabular}{|c|c|c|c|c|c|c|}
\hline Document & Keywords & Classification & Context & $L C$ & Methods & Findings \\
\hline $\begin{array}{l}\text { Casillas, J., \& Martínez- } \\
\text { López, F. J. (2009). } \\
\text { Mining uncertain data } \\
\text { with multiobjective genetic } \\
\text { fuzzy systems to be applied } \\
\text { in consumer behavior } \\
\text { modeling. Expert Systems } \\
\text { with Applications, 36(2), } \\
\text { 1645-1659. }\end{array}$ & $\begin{array}{l}\text { Consumer behavior; Fuzzy } \\
\text { logic; Genetic algorithms; } \\
\text { Knowledge extraction; } \\
\text { Machine learning; } \\
\text { Marketing }\end{array}$ & $\begin{array}{l}\text { Effective selling; } \\
\text { NPD }\end{array}$ & $\begin{array}{l}\text { Consumer } \\
\text { behavior setting }\end{array}$ & 3 & $\begin{array}{l}\text { Machine } \\
\text { learning } \\
\text { techniques }\end{array}$ & $\begin{array}{l}\text { This study targets } \\
\text { machine learning } \\
\text { techniques in data } \\
\text { collection, data } \\
\text { mining, and knowledge } \\
\text { interpretation in the } \\
\text { marketing field. }\end{array}$ \\
\hline $\begin{array}{l}\text { Bhattacharyya, } S . \\
\text { (1999). Direct marketing } \\
\text { performance modeling using } \\
\text { genetic algorithms. INFORMS } \\
\text { Journal on Computing, 11(3), } \\
248-257 \text {. }\end{array}$ & $\begin{array}{l}\text { Genetic algorithms, } \\
\text { data mining, database } \\
\text { marketing, profile } \\
\text { modeling, resampling }\end{array}$ & $\begin{array}{l}\text { Effective selling; } \\
\text { pricing }\end{array}$ & $\begin{array}{l}\text { Pure } \\
\text { mathematical } \\
\text { modelling }\end{array}$ & 2 & $\begin{array}{l}\text { Genetic } \\
\text { algorithm } \\
\text { based machine } \\
\text { learning } \\
\text { techniques }\end{array}$ & $\begin{array}{l}\text { A new machine learning } \\
\text { algorithm is found to be } \\
\text { effective in predicting } \\
\text { direct marketing } \\
\text { performance. }\end{array}$ \\
\hline $\begin{array}{l}\text { Balakrishnan, P. V., Gupta, } \\
\text { R., \& Jacob, V. S. (2004). } \\
\text { Development of hybrid } \\
\text { genetic algorithms for } \\
\text { product line designs. IEEE } \\
\text { Transactions on Systems, } \\
\text { Man, and Cybernetics, Part } \\
\text { B (Cybernetics), 34(1), } \\
468-483 \text {. }\end{array}$ & $\begin{array}{l}\text { Artificial intelligence, } \\
\text { attribute importance, beam } \\
\text { search, GA, hybrid genetic } \\
\text { algorithms, marketing, } \\
\text { meta-heuristic techniques. }\end{array}$ & NPD & $\begin{array}{l}\text { Pure } \\
\text { mathematical } \\
\text { modelling }\end{array}$ & 2 & $\begin{array}{l}\text { Artificial } \\
\text { intelligence } \\
\text { (AI) based } \\
\text { meta-heuristic } \\
\text { techniques } \\
\text { namely genetic } \\
\text { algorithms }\end{array}$ & $\begin{array}{l}\text { This study finds AI is } \\
\text { effective in designing } \\
\text { product lines. }\end{array}$ \\
\hline $\begin{array}{l}\text { Shin, H., \& Cho, S. (2006). } \\
\text { Response modeling with } \\
\text { support vector machines. } \\
\text { Expert Systems with } \\
\text { Applications, } 30(4), 746-760 .\end{array}$ & $\begin{array}{l}\text { Response modeling; } \\
\text { Direct marketing; Support } \\
\text { vector machines (SVMs); } \\
\text { Pattern selection; Class } \\
\text { imbalance; Scoring }\end{array}$ & Pricing & $\begin{array}{l}\text { Pure } \\
\text { mathematical } \\
\text { modelling }\end{array}$ & 2 & $\begin{array}{l}\text { Support Vector } \\
\text { Machine (SVM) }\end{array}$ & $\begin{array}{l}\text { This study designs } \\
\text { effective response } \\
\text { modeling with support } \\
\text { vector machines. }\end{array}$ \\
\hline $\begin{array}{l}\text { Martínez-López, F. J., \& } \\
\text { Casillas, J. (2009). Marketing } \\
\text { Intelligent Systems for } \\
\text { consumer behavior modeling } \\
\text { by a descriptive induction } \\
\text { approach based on Genetic } \\
\text { Fuzzy Systems. Industrial } \\
\text { Marketing Management, } \\
\text { 38(7), 714-731. }\end{array}$ & $\begin{array}{l}\text { Marketing modelling; } \\
\text { Management support; } \\
\text { Analytical method; } \\
\text { Knowledge discovery; } \\
\text { Genetic Fuzzy Systems; } \\
\text { Methodology }\end{array}$ & CRM & $\begin{array}{l}\text { Consumer } \\
\text { behavior setting }\end{array}$ & 2 & $\begin{array}{l}\text { Genetic Fuzzy } \\
\text { Systems, } \\
\text { a specific } \\
\text { hybridization } \\
\text { of artificial } \\
\text { intelligence } \\
\text { methods. }\end{array}$ & $\begin{array}{l}\text { A new machine learning } \\
\text { technique is used in } \\
\text { marketing intelligent } \\
\text { system to model } \\
\text { consumer behavior. }\end{array}$ \\
\hline $\begin{array}{l}\text { Ikeda, K., Hattori, G., Ono, } \\
\text { C., Asoh, H., \& Higashino, T. } \\
\text { (2013). Twitter user profiling } \\
\text { based on text and community } \\
\text { mining for market analysis. } \\
\text { Knowledge-Based Systems, } \\
\text { 51,35-47. }\end{array}$ & $\begin{array}{l}\text { Web mining; Market } \\
\text { analysis; User profiling; } \\
\text { Twitter; Text analysis; } \\
\text { Community analysis; } \\
\text { Machine learning }\end{array}$ & CRM & Tweets & 2 & $\begin{array}{l}\text { A hybrid } \\
\text { text-based and } \\
\text { community- } \\
\text { based method }\end{array}$ & $\begin{array}{l}\text { Data mining techniques } \\
\text { are used to reveal twitter } \\
\text { user profiles. }\end{array}$ \\
\hline $\begin{array}{l}\text { Kwok, L., \& Yu, B. (2013). } \\
\text { Spreading social media } \\
\text { messages on Facebook: } \\
\text { An analysis of restaurant } \\
\text { business-to-consumer } \\
\text { communications. Cornell } \\
\text { Hospitality Quarterly, 54(1), } \\
\text { 84-94. }\end{array}$ & $\begin{array}{l}\text { social media, } \\
\text { Facebook, marketing, } \\
\text { communication, } \\
\text { restaurant, text } \\
\text { classification }\end{array}$ & $\begin{array}{l}\text { Effective selling: } \\
\text { CRM }\end{array}$ & Facebook & 2 & $\begin{array}{l}\text { Text } \\
\text { classification }\end{array}$ & $\begin{array}{l}\text { Text classification } \\
\text { technique is used to } \\
\text { analyze restaurant } \\
\text { business to consumer } \\
\text { communications on } \\
\text { Facebook. }\end{array}$ \\
\hline $\begin{array}{l}\text { Poria, S., Gelbukh, A., } \\
\text { Cambria, E., Hussain, A., } \\
\& \text { Huang, G. B. (2014). } \\
\text { EmoSenticSpace: A novel } \\
\text { framework for affective } \\
\text { common-sense reasoning. } \\
\text { Knowledge-Based Systems, } \\
69,108-123 .\end{array}$ & $\begin{array}{l}\text { Sentic computing; Opinion } \\
\text { mining; Sentiment } \\
\text { analysis; Emotion } \\
\text { recognition; Personality } \\
\text { detection; Fuzzy clustering }\end{array}$ & CRM & EmoSenticSpace & 2 & $\begin{array}{l}\text { Natural } \\
\text { language } \\
\text { processing; } \\
\text { sentiment } \\
\text { analysis }\end{array}$ & $\begin{array}{l}\text { Emotion recognition } \\
\text { and sentiment analysis } \\
\text { are used for effective } \\
\text { common-sense } \\
\text { reasoning. }\end{array}$ \\
\hline
\end{tabular}

Note: (1) LC means location citation, how many times the paper is being cited within the 628 articles. 
article is from Chang et al. (2005). Their work applied a neural network technique to compare the before and after sales forecasts. The results demonstrate that AI tools are effective in predicting sales.

\section{Theme 2: Customer Relationship Management}

In marketing studies, emotions play a crucial role in linguistic understanding and common sense reasoning. Prior machine-learning tools find it difficult to interpret emoticons accurately. A new framework, EmoSentic Space, was proposed by Poria et al. (2014) to provide emotional labels and scores for a large set of natural language concepts. EmoSenticSpace can reach a $92.15 \%$ accuracy rate in a comparison of standard facial expressions and body language. In a social broadcasting network (e.g., Facebook, Twitter, and Instagram), customer word of mouth can be monitored and analyzed for customer relationship management. Many researchers suggest that managers who want to leverage SBN (social broadcasting network) should implement machine learning tools to identify and monitor people's attitudes towards influential topics (Rui et al., 2013; Kwok \& Yu, 2013; Ikeda et al., 2013). SBN and machine learning techniques are effective combinations to upgrade customer relationship qualities. Machine learning techniques can be used to improve customer relationship management by identifying customer emotions and tailoring corresponding strategies.

\section{Theme 3: New Product Development}

A central problem in new product development is to understand customer preferences. Traditionally, marketers use a pre-determined questionnaire to ask respondent preferences about new product designs. But with the development of machine learning techniques, the adaptive questionnaire has gained increasing interest among researchers and practitioners (Abernethy et al., 2008). The questions can be redesigned based on the respondent's previous response. This tailored questionnaire has led to a significant increase in the new product development success rate (Abernethy et al., 2008). AI-based tools can also upgrade product line design. Balakrishnan et al. (2004) empirically demonstrated the efficacy of AI-based techniques (such as genetic algorithms) in solving product line design problems. New product development (NPD) is a complex decision-making process. Idea generation requires a significant amount of creativity. The newly developed machine learning techniques change the traditional paradigm in new product development. These results and applications also encourage the further exploration of more AI-based tools in NPD.

\section{Theme 4: Advertising and Promotion}

Advertising and promotion represent another important research stream in marketing literature that machine learning techniques have upgraded. Kwok and Yu (2013) found that spreading social media messages on Facebook was an effective promotional method. Social media is one representative online channel. Research has found its effectiveness in targeting more promotions. For marketers, we need to identify other platforms (e.g., programmatic advertising, Google advertising) that also show efficacy in implementing promotional strategies-finding out and demonstrating that evidence will provide valuable suggestions to managers.

\section{Theme 5: Pricing}

Effective pricing is used to identify people's purchase likelihood towards different tailored prices. Shin and Cho (2006) proposed a response model (using support vector machine techniques) to predict the probability that a customer will respond to a promotional pricing offer. Using this model, marketers can identify a subset of customers who are more likely to react than others and adjust the pricing accordingly. Bhattacharyya (1999) also explored models in identifying the most promising customers to mail to and their most likely accepting price. Machine learning modeling is used to identify customers such that the overall profit from marketing activities, considering promotional costs, pricing, and functional costs, is maximized (Cui et al., 2006; Cui \& Curry, 2005; Ghose et al., 2012). Pricing is always an interesting section in marketing studies. Dynamic pricing, which changes 
based on demands, supplies, customer characteristics, and external environments, gained growing popularity among AI pioneers. The most cited evidence discussing dynamic pricing also gives future scholars confidence in identifying more AI-based applications that facilitate dynamic pricing.

\subsection{Social Network Analysis Results}

Next, we conducted a social network analysis (SNA) to understand this leading research field. There are three concepts associated with social network mapping: node, edge, and cluster. The size of a node (circle) represents the frequency of the item; the edge (line) represents the relationship between items; the node's color represents the cluster; the thickness of the edge represents the frequency of two items that show together.

\subsubsection{Institutional SNA}

Further exploration involves analyzing the universities' collaboration network about AIM studies (as shown in figure 3). This SNA not only indicates the institutional clusters it also identifies the top universities in AIM studies. There are five clusters identified. The red cluster shows that MIT, Carnegie Mellon University, Nanyang Technology University, Columbia University, and the University of Pennsylvania have a strong collaboration network. Hong Kong Polytech University, City University of Hong Kong, and the University of Texas are another collaboration cluster (green color). California is another research concentrated region for AIM studies as Stanford University, University of California San Diego, University of California Berkeley, and University of Southern California collaborate a lot.

Figure 3. Collaboration network about AIM studies

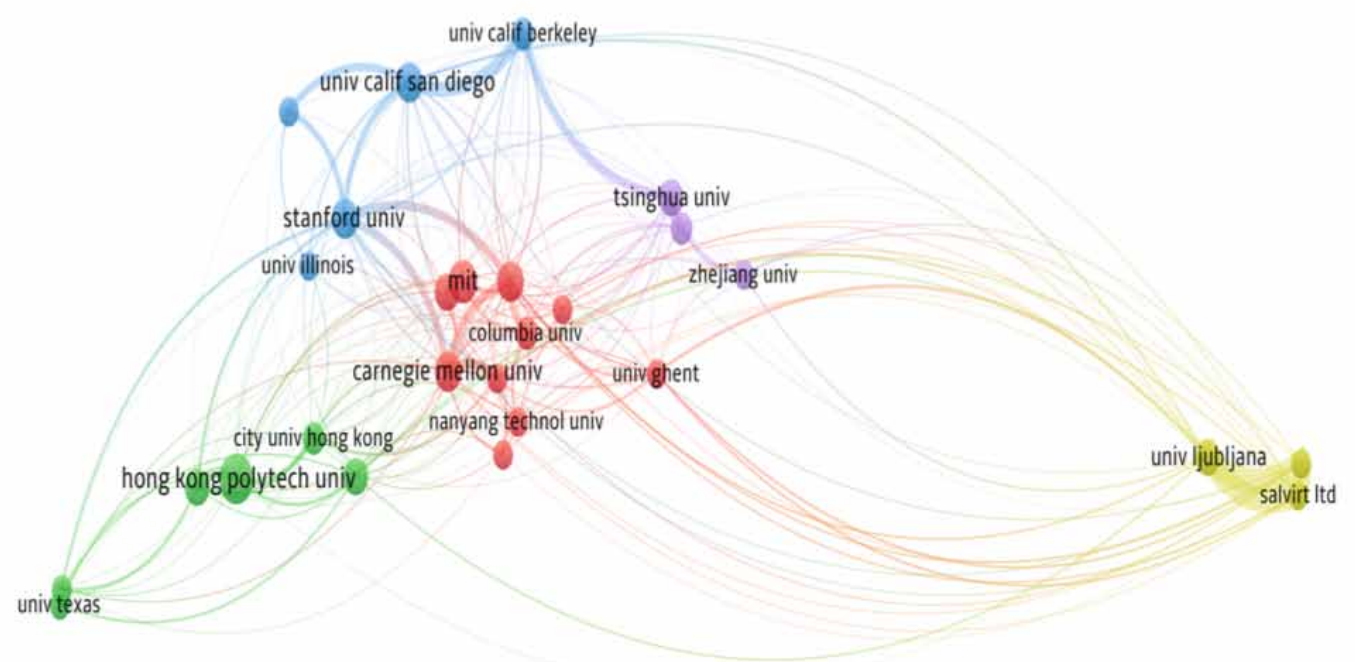

By looking deeper into each cluster, we found interesting potential research areas. For instance, Carnegie Mellon University and the University of Pennsylvania have worked on research that examines advertising content and consumer engagement on social media (Lee et al., 2018). They collected social media advertising data from Facebook and conducted a natural language processing algorithm to analyze 106,316 Facebook messages across 782 companies. The results provide strong 
evidence that Facebook is an effective advertising and promotion platform. Tsinghua University and the University of California, Berkeley published a paper: "Concept Clustering in Design Teams: a Comparison Between Human and Machine Clustering" (Zhang et al., 2017). This research used a machine learning approach to analyze natural language descriptions in comparing human and machine performance on clustering 1000 new product concepts. Results show that machines are good performers in identifying "over-clustering" and "under-clustering," but humans show superiorities in other tasks, such as generating creative ideas. This publication indicates that AI will not replace humans; the primary function of $\mathrm{AI}$ is still to augment human conversations and relieve humans from mundane tasks.

\subsubsection{Keyword Plus SNA}

To better understand the leading research field, we conducted a keyword analysis for the 628 published articles. It identified the most frequently used keywords on these topics. Keyword analysis can be used to identify evolving research frontiers relating to a knowledge domain. Keywords plus SNA are used to determine the most valuable keywords and reveal the citation of keywords in promising papers derived from the dataset. Figure 4 shows the keyword occurrence network. This study identifies five different color clusters.

\section{Figure 4. Keyword occurrence network}

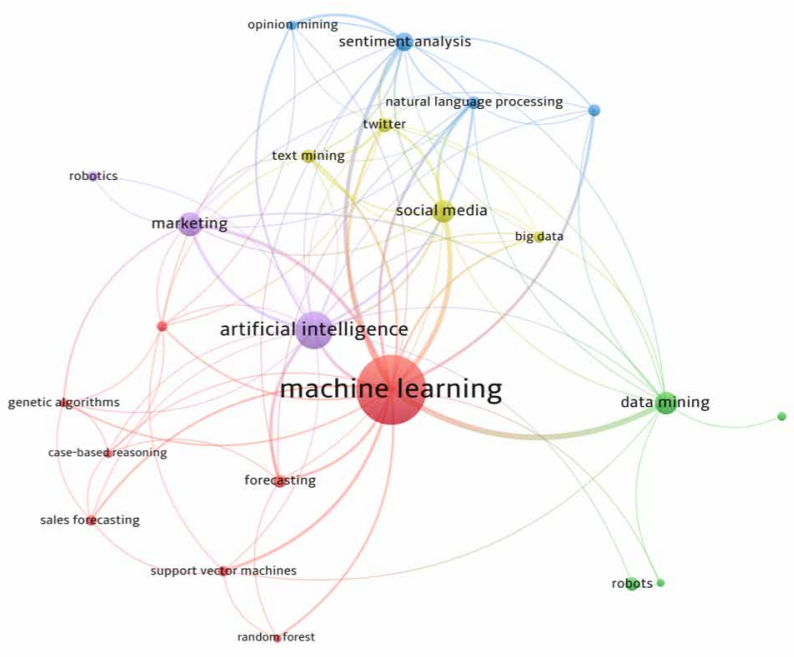

The first cluster has major nodes associated with machine learning, classification, data mining, algorithm, and big data. This cluster emphasizes the role of big data and data analytics in revealing the data structures, characteristics, and functions in AIM research. The second cluster corresponds to the academic research activities that examined social media, sentiment analysis, natural language processing, online review, word of mouth, and sales. Actually, natural language processing, online reviews, and social media have been hot topics in digital marketing studies for a while. The third cluster is more performance-oriented, including performance, management, information, behavior, knowledge, and innovation. This cluster provides a theoretical foundation to link artificial intelligence and firm performance. Knowledge generation, innovation diffusion, and dynamic capability building 
could be potential paths. The fourth cluster deals with the keywords of model, algorithm, optimization, system, and design. These words are much more technical-oriented. Besides theoretical development, marketing scholars also tap into technical applications. The fifth cluster incorporates the keywords of artificial intelligence, forecasting, robotic, and marketing. The node size of artificial intelligence is relatively smaller than machine learning, but the edges that link them are thick. The popularity of artificial intelligence research is constantly growing. This suggests significant opportunities for marketing scholars.

The keywords plus SNA provides us a good picture of the current state of AIM studies and the potential theoretical foundation that links AI to marketing performance (e.g., a theory of knowledge generation, innovation diffusion, and dynamic capability building).

\subsection{Main Path Analysis of the Milestone Papers}

Donthu et al. (2020) show scientific works demonstrate collaborations through their references. When two articles cite the same third article, all three articles fall in a similar stream of research. Article citations form a network through which there are many influential paths. The main path is based on the importance of the citation link to identify the most significant path. The importance of each citation is measured by the number of times a citation link has been traversed if one exhausts the search from a set of starting nodes to another set of ending nodes.

Figure 5 reveals the main path and the relevant publications corresponding to the milestone papers with an arrow. It is necessary to emphasize that main path analysis is not necessarily defined by the most cited papers (Liu \& Lu, 2012). In total, there are eleven milestone papers identified through main path analysis using key-routes search techniques. Figure 5 shows a clustered network in which each node represents one article, and the node size is proportional to the number of citations of this paper. The edge between the nodes means there is a citation link between these two papers. The main path network is a directed network. Each cluster indicates a research field or a theoretical stream. The main path analysis shows a total of four clusters with eleven milestone articles.

Figure 5. Main path and relevant publications by milestone

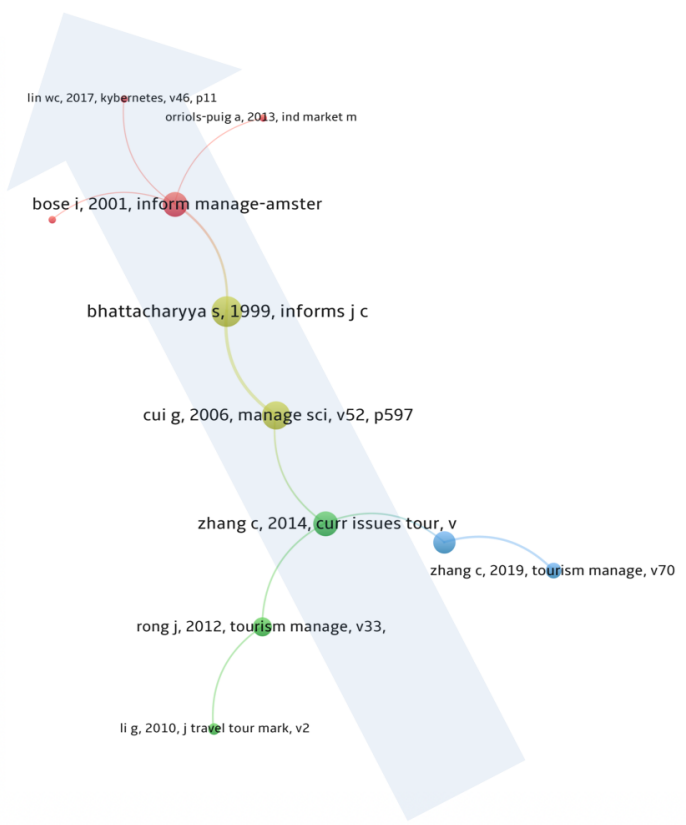


Table 6. The main path analysis documents

\begin{tabular}{|c|c|c|c|c|c|}
\hline Cluster & Articles & Keywords & Context & Methods & Findings \\
\hline \multirow{4}{*}{$\begin{array}{l}\text { Cluster 1: } \\
\text { machine learning } \\
\text { techniques in } \\
\text { business such } \\
\text { as customer } \\
\text { relationship } \\
\text { management, } \\
\text { sales, publishing, } \\
\text { online sales, and } \\
\text { advertisement }\end{array}$} & $\begin{array}{l}\text { Bose, I., \& Mahapatra, R. } \\
\text { K. (2001). Business data } \\
\text { mining-a machine learning } \\
\text { perspective. Information } \\
\text { \& management, 39(3), } \\
\text { 211-225.Information } \\
\text { \& management, 39(3), } \\
\text { 211-225. }\end{array}$ & $\begin{array}{l}\text { Business } \\
\text { applications; Data } \\
\text { mining; Machine } \\
\text { learning }\end{array}$ & Business & $\begin{array}{l}\text { A survey of } \\
\text { data mining } \\
\text { applications } \\
\text { in business is } \\
\text { provided to } \\
\text { investigate the } \\
\text { use of learning } \\
\text { techniques. }\end{array}$ & $\begin{array}{l}\text { Rule induction (RI) was found to be most } \\
\text { popular, followed by neural networks } \\
\text { (NNs) and case-based reasoning (CBR). } \\
\text { Most applications were found in financial } \\
\text { areas, where prediction of the future was a } \\
\text { dominant task category. }\end{array}$ \\
\hline & $\begin{array}{l}\text { Lin, W. C., Ke, S. W., \& } \\
\text { Tsai, C. F. (2017). Top } 10 \\
\text { data mining techniques in } \\
\text { business applications: a brief } \\
\text { survey. Kybernetes, 46(7), } \\
\text { 1158-1170. }\end{array}$ & $\begin{array}{l}\text { data mining; } \\
\text { business } \\
\text { applications; } \\
\text { machine learning; } \\
\text { survey }\end{array}$ & Business & $\begin{array}{l}\text { Examine related } \\
\text { surveys in the } \\
\text { literature and } \\
\text { thus identify the } \\
\text { frequently applied } \\
\text { data mining } \\
\text { techniques }\end{array}$ & $\begin{array}{l}\text { There are thirty-three different data mining } \\
\text { techniques employed in eight different } \\
\text { application areas. Most of them are } \\
\text { supervised learning techniques and the } \\
\text { application area where such techniques are } \\
\text { most often seen is bankruptcy prediction, } \\
\text { followed by the areas of customer } \\
\text { relationship management, fraud detection, } \\
\text { intrusion detection, and recommender } \\
\text { systems. }\end{array}$ \\
\hline & $\begin{array}{l}\text { Miralles-Pechuán, L., Rosso, } \\
\text { D., Jiménez, F., \& García, J. } \\
\text { M. (2017). A methodology } \\
\text { based on Deep Learning } \\
\text { for advert value calculation } \\
\text { in CPM, CPC and CPA } \\
\text { networks. Soft Computing, } \\
\text { 21(3), 651-665. }\end{array}$ & $\begin{array}{l}\text { Advertisement } \\
\text { value calculation } \\
\text { in CPM, CPC and } \\
\text { CPA networks; } \\
\text { Deep Learning } \\
\text { methods in online } \\
\text { advertising; } \\
\text { Sales prediction; } \\
\text { Spam probability } \\
\text { calculation; CTR } \\
\text { estimation; Deep } \\
\text { Learning in } \\
\text { advertisement value } \\
\text { calculation }\end{array}$ & Advertising & $\begin{array}{l}\text { Based on machine } \\
\text { learning and } \\
\text { deep learning } \\
\text { methods to } \\
\text { calculate the advert } \\
\text { value in CPM } \\
\text { (Cost-per-mille), } \\
\text { CPC (Cost-per- } \\
\text { click), and CPA } \\
\text { (Cost-per-action) } \\
\text { networks. }\end{array}$ & $\begin{array}{l}\text { DL (deep learning) is a supervised method } \\
\text { that is very efficient in the classification of } \\
\text { spam adverts and in the estimation of the } \\
\text { CTR (click-through rate). In the prediction } \\
\text { of online sales, DLNN (Deep Learning } \\
\text { Neural Networks) have shown, on average, } \\
\text { worse performance than cubist and random } \\
\text { forest methods, although better performance } \\
\text { than model tree, model rules, and linear } \\
\text { regression methods. }\end{array}$ \\
\hline & $\begin{array}{l}\text { Orriols-Puig, A., Martínez- } \\
\text { López, F. J., Casillas, } \\
\text { J., \& Lee, N. (2013). } \\
\text { Unsupervised KDD to } \\
\text { creatively support managers' } \\
\text { decision making with } \\
\text { fuzzy association rules: } \\
\text { A distribution channel } \\
\text { application. Industrial } \\
\text { Marketing Management, } \\
\text { 42(4), 532-543. }\end{array}$ & $\begin{array}{l}\text { Intelligent } \\
\text { systems; KDD; } \\
\text { Unsupervised } \\
\text { learning; } \\
\text { Management } \\
\text { support; Genetic } \\
\text { fuzzy systems }\end{array}$ & Marketing & $\begin{array}{l}\text { A novel intelligent } \\
\text { system that } \\
\text { incorporates } \\
\text { fuzzy logic and } \\
\text { genetic algorithms } \\
\text { to operate in an } \\
\text { unsupervised } \\
\text { manner. }\end{array}$ & $\begin{array}{l}\text { The proposed system can return a number of } \\
\text { novel and potentially interesting associations } \\
\text { among variables. It has significant potential } \\
\text { to improve the analysis of marketing and } \\
\text { business databases in practice, especially in } \\
\text { non-programmed decisional scenarios, as } \\
\text { well as to assist scholarly researchers in their } \\
\text { exploratory analysis. }\end{array}$ \\
\hline \multirow{3}{*}{$\begin{array}{l}\text { Cluster 2: } \\
\text { machine learning } \\
\text { in outbound } \\
\text { tourism to plan } \\
\text { more effective } \\
\text { targeted } \\
\text { marketing } \\
\text { strategies. }\end{array}$} & $\begin{array}{l}\text { Li, G., Law, R., Rong, } \\
\text { J., \& Vu, H. Q. (2010). } \\
\text { Incorporating both positive } \\
\text { and negative association } \\
\text { rules into the analysis of } \\
\text { outbound tourism in Hong } \\
\text { Kong. Journal of travel \& } \\
\text { tourism marketing, 27(8), } \\
812-828 .\end{array}$ & $\begin{array}{l}\text { Contrast analysis, } \\
\text { association rules, } \\
\text { machine learning, } \\
\text { data mining, Hong } \\
\text { Kong, outbound } \\
\text { tourism }\end{array}$ & $\begin{array}{l}\text { Three } \\
\text { large-scale } \\
\text { domestic } \\
\text { tourism } \\
\text { surveys }\end{array}$ & $\begin{array}{l}\text { A novel approach } \\
\text { to data mining } \\
\text { that incorporates } \\
\text { both positive } \\
\text { and negative } \\
\text { association rules } \\
\text { into the analysis of } \\
\text { outbound travelers. }\end{array}$ & $\begin{array}{l}\text { The negative rules provide a new tool for } \\
\text { tourism practitioners and policymakers } \\
\text { to understand the patterns of outbound } \\
\text { tourism based on datasets that comprise } \\
\text { common demographic and behavioral } \\
\text { characteristics. The discovered negative rules } \\
\text { can then be applied to marketing strategies, } \\
\text { enabling costs to be reduced by avoiding the } \\
\text { unnecessary expense of promotion to the } \\
\text { unpromising groups of potential customers. }\end{array}$ \\
\hline & $\begin{array}{l}\text { Rong, J., Vu, H. Q., Law, } \\
\text { R., \& Li, G. (2012). A } \\
\text { behavioral analysis of web } \\
\text { sharers and browsers in } \\
\text { Hong Kong using targeted } \\
\text { association rule mining. } \\
\text { Tourism Management, } \\
\text { 33(4), 731-740. }\end{array}$ & $\begin{array}{l}\text { Sharers; Browsers; } \\
\text { Electronic } \\
\text { word-of-mouth; } \\
\text { Association rules; } \\
\text { Machine learning; } \\
\text { Data mining; Hong } \\
\text { Kong; Outbound } \\
\text { tourism }\end{array}$ & $\begin{array}{l}\text { Tourism } \\
\text { industry }\end{array}$ & $\begin{array}{l}\text { Rule mining } \\
\text { techniques }\end{array}$ & $\begin{array}{l}\text { Young people are more likely to search for } \\
\text { travel information and share their travel } \\
\text { experience online than old people. Both } \\
\text { education and income levels are found to } \\
\text { be the key factors influencing the behavior } \\
\text { of respondents in seeking travel-related } \\
\text { information. }\end{array}$ \\
\hline & $\begin{array}{l}\text { Zhang, C., \& Zhang, J. } \\
\text { (2014). Analysing Chinese } \\
\text { citizens' intentions of } \\
\text { outbound travel: a machine } \\
\text { learning approach. Current } \\
\text { Issues in Tourism, 17(7), } \\
\text { 592-609. }\end{array}$ & $\begin{array}{l}\text { travel intention, } \\
\text { outbound travel, } \\
\text { machine learning, } \\
\text { twice-learning, } \\
\text { personal } \\
\text { characteristic }\end{array}$ & $\begin{array}{l}\text { Chinese } \\
\text { outbound } \\
\text { tourists }\end{array}$ & $\begin{array}{l}\text { Twice-learning } \\
\text { machine learning } \\
\text { technique }\end{array}$ & $\begin{array}{l}\text { Young people, females, and highly educated } \\
\text { people in this life-cycle stage usually have } \\
\text { adequate time, money and energy for leisure. } \\
\text { This makes it possible for their long-haul } \\
\text { travel, such as outbound travel. }\end{array}$ \\
\hline
\end{tabular}


Table 6. Continued

\begin{tabular}{|c|c|c|c|c|c|}
\hline Cluster & Articles & Keywords & Context & Methods & Findings \\
\hline \multirow{2}{*}{$\begin{array}{l}\text { Cluster 3: } \\
\text { machine learning } \\
\text { techniques } \\
\text { in marketing } \\
\text { strategies for } \\
\text { predicting and } \\
\text { classifying } \\
\text { tourists. }\end{array}$} & $\begin{array}{l}\text { Zhang, C., \& Huang, Z. } \\
(2015) \text {. Mining tourist } \\
\text { motive for marketing } \\
\text { development via twice- } \\
\text { learning. Applied Artificial } \\
\text { Intelligence, 29(2), 119-133. }\end{array}$ & Marketing; Model & $\begin{array}{l}\text { Tourism } \\
\text { industry }\end{array}$ & $\begin{array}{l}\text { Twice-learning } \\
\text { framework }\end{array}$ & $\begin{array}{l}\text { Two-phase learning process can predict } \\
\text { tourist motives accurately as well as extract } \\
\text { meaningful insights, which are useful for } \\
\text { targeted marketing strategies development } \\
\text { from the real-world data. }\end{array}$ \\
\hline & $\begin{array}{l}\text { Zhang, C., Huang, Z., Cao, } \\
\text { F., \& Chen, X. (2019). } \\
\text { Recognise me from outside } \\
\text { to inside: Learning the } \\
\text { influence chain of urban } \\
\text { destination personalities. } \\
\text { Tourism Management, 70, } \\
\text { 390-403. }\end{array}$ & $\begin{array}{l}\text { Urban destination } \\
\text { personality; Urban } \\
\text { landscape; Overall } \\
\text { destination image; } \\
\text { Influence chain; } \\
\text { Machine learning }\end{array}$ & $\begin{array}{l}\text { Tourism } \\
\text { industry }\end{array}$ & $\begin{array}{l}\text { Machine learning } \\
\text { data analysis tool }\end{array}$ & $\begin{array}{l}\text { Urban destination personalities have an } \\
\text { impact on overall destination image, and } \\
\text { they mediate the relationship between urban } \\
\text { landscapes and overall destination image. }\end{array}$ \\
\hline \multirow[b]{2}{*}{$\begin{array}{l}\text { Cluster 4: } \\
\text { machine learning } \\
\text { and modeling for } \\
\text { direct marketing. }\end{array}$} & $\begin{array}{l}\text { Bhattacharyya, S. } \\
\text { (1999). Direct marketing } \\
\text { performance modeling } \\
\text { using genetic algorithms. } \\
\text { INFORMS Journal on } \\
\text { Computing, 11(3), 248-257. }\end{array}$ & $\begin{array}{l}\text { Genetic algorithms, } \\
\text { data mining, } \\
\text { database marketing, } \\
\text { profile modeling, } \\
\text { resampling }\end{array}$ & $\begin{array}{l}\text { Direct } \\
\text { marketing }\end{array}$ & Genetic algorithm & $\begin{array}{l}\text { This algorithm is effective in identifying the } \\
\text { most promising individuals to mail to and } \\
\text { thus maximize returns from solicitations. }\end{array}$ \\
\hline & $\begin{array}{l}\text { Cui, G., Wong, M. L., \& } \\
\text { Lui, H. K. (2006). Machine } \\
\text { learning for direct marketing } \\
\text { response models: Bayesian } \\
\text { networks with evolutionary } \\
\text { programming. Management } \\
\text { Science, 52(4), 597-612. }\end{array}$ & $\begin{array}{l}\text { direct marketing; } \\
\text { Bayesian networks; } \\
\text { evolutionary } \\
\text { programming; } \\
\text { machine learning; } \\
\text { data mining }\end{array}$ & $\begin{array}{l}\text { Direct } \\
\text { marketing }\end{array}$ & $\begin{array}{l}\text { Bayesian networks, } \\
\text { neural networks, } \\
\text { classification and } \\
\text { regression tree } \\
\text { (CART), and latent } \\
\text { class regression }\end{array}$ & $\begin{array}{l}\text { Bayesian networks have distinct advantages } \\
\text { over the other methods in accuracy of } \\
\text { prediction, transparency of procedures, } \\
\text { interpretability of results, and explanatory } \\
\text { insight. Our findings lend strong support } \\
\text { to Bayesian networks as a robust tool for } \\
\text { modeling consumer response and other } \\
\text { marketing problems and for assisting } \\
\text { management decision making. }\end{array}$ \\
\hline
\end{tabular}

Table 6 shows the eleven milestone papers in the main path analysis. Based on comprehensive content analysis, we summarized those documents into the following clusters.

Cluster 1---machine learning techniques in business: such as CRM, sales, publishing, online sales, and advertisement--- consists of four items: Bose and Mahapatra (2001); Lin et al. (2017); Miralles-Pechuán et al. (2017), and Orriols-Puig et al. (2013). This cluster compares the business effectiveness of a series of machine learning techniques (e.g., rule induction, neural networks, and supervised learning). Bose and Mahapatra (2001) and Lin et al. (2017) conducted surveys to systematically and comprehensively compare those machine learning techniques. In general, there are over thirty-three different data mining techniques employed in various business areas. Most of them are supervised machine learning techniques that are used in bankruptcy prediction, fraud detection, intrusion detection, recommender systems, and customer relationship management. Rule induction (RI) was found to be the most popular, followed by neural networks (NNs) and case-based reasoning (CBR) in financial prediction. At the same time, marketing advertising by deep learning is very efficient in classifying spam advertisements and estimating CTR (click-through rate). In predicting online sales, DLNN (deep learning neural network) has shown, on average, a poorer performance than cubist and random forecast methods. But, DLNN has demonstrated better performance than the model tree, model rules, and linear regression methods. This cluster provides a good technological foundation for researchers who want to work on AIM studies.

Cluster 2---machine learning in outbound tourism to plan more effective targeted marketing strategies--- consists of three items: Li et al. (2010), Rong et al. (2012), and Zhang and Zhang (2014). Unlike the first cluster that is more technologically oriented, the second cluster emphasizes how managers could leverage machine learning techniques to plan their marketing strategies. Those strategies include but are not limited to business planning, marketing positioning, marketing targeting, and advertising. The main managerial contribution of this cluster is that managers can take the 
suggestions from those papers and tailor them to their marketing activities. This cluster provides significant recommendations to practitioners and policymakers to understand the patterns of outbound tourism based on datasets that incorporate common demographic and behavioral characteristics. For instance, young people are more likely than older adults to search for travel information and share their travel experiences online. Both education and income levels are found to be critical factors that influence customers to seek travel-related information. Young people, females, and highly educated people usually have adequate time, money, and energy for leisure. The second cluster rests on the tourism industry. Rule mining techniques and a twice-learning framework are effective in cultivating customer relationships and providing customized service. This cluster offers persuasive evidence demonstrating how machine learning techniques could be used to enhance customer relationship management and the firm's selling capabilities.

Cluster 3---machine learning techniques in marketing strategies for predicting and classifying tourists--- consists of two items: Zhang and Huang (2015) and Zhang et al. (2019). The third cluster is a supplement to the second one. It also examines the role of AI in augmenting the effectiveness of marketing strategies, but the marketing strategies focus much more on predicting and classifying customers. Specifically, this cluster deals with two data limitations that happened widely in most marketing research. The first limitation is to construct a model that can generate accurate and comprehensive predictions. The second limitation is the small and noisy data collected from tourists. The two-phase learning process is found to predict correct tourist motives and extract meaningful insights from those actions. This technique demonstrates its effectiveness in effective selling and personalized advertising.

Cluster 4--- machine learning and modeling for direct marketing-consists of two items: Bhattacharyya (1999) and Cui et al. (2006). This cluster examines how to deploy AI to help the firm build a sustainable customer relationship. Because AI could directly approach and serve customers, customer relationship management has undergone a disruptive change due to applying AI tools.

\section{SUMMARY AND CONCLUSION}

The inaugural of AI in marketing research contained five articles annually from 1982 to 2012. Since then, the publications have grown exponentially. In 2018, the number of annual publications surged to 125 , almost five times the sum of the past 30 years, suggesting that interest in the topic will continue to grow. The institutions most often affiliated with AIM studies are top research-oriented universities. Those schools include MIT, Carnegie Mellon University, Nanyang Technology University, Columbia University, University of Pennsylvania, Hong Kong Polytech University, City University of Hong Kong, and the University of Texas, Stanford University, University of California San Diego, University of California Berkeley, University of Southern California, Tsing University, and Zhejiang University.

The top 10 authors are researching AI in B2B sales forecasting, machine learning acceptance model, and machine learning knowledge generation and diffusion. Effective selling, customer relationship management (CRM), new product development (NPD), advertising and promotion, and pricing are identified by top-cited articles and main path analysis as the most common marketing activities that have used AI tools.

Effective selling, especially sales forecasting and prediction, is greatly empowered by AI tools. Research in this area can help sales managers understand how to use AI to maximize selling efforts, when and where AI might be most productive. Customer relationship management is the second field that benefits most from AI tools. AI, especially the virtual assistant and chatbot, can work like a service provider and frontline employee to increase customer-employee interface effectiveness. Research on the interaction of AI and frontline employees might provide helpful insight for marketing and sales managers. AI tools could also upgrade the new product development process. Those tools can detect the underlying mechanisms and relationships among the data to facilitate the firm's creative idea generation. Research on the use of AI in each stage of the new product development process could 
help shorten the new product development process, bringing products to market more quickly than competitors.

AI tools could also augment advertising and promotion. The speedy reaction and big data encompassed in AI tools enable firms to target the right customers at the right time and send them the right advertising messages. Since AI helps firms change notifications to meet customers' needs more quickly and accurately, research might examine differences in advertising appeal changes in consumer versus business markets.

Another important activity that AI tools can augment is pricing. Dynamic pricing is not a new research field. This field has been an active research stream for years, but AI tools have updated the firm's dynamic pricing capability to a higher level. AI can enable firms to automatically change the price to reflect the demand changes faster and more efficiently. Research in dynamic pricing for business markets based on AI might be useful for sales managers. Additionally, examining the effective use of AI in various pricing situations might be helpful. For example, having current pricing information about competitor products might be helpful in straight rebuy, modified rebuy, or new buy situations to quite different degrees.

In conclusion, the literature review, top authors leading publications, most cited papers, and the main path clusters show strong, informative signals for marketers to conduct high-quality research. AI is the leading force for societal advancement; with the emergence of AI, a new paradigm of the human-machine interface is on the horizon, and managers should exhibit a more open mindset to adopt $\mathrm{AI}$ and use it in realizing business efficiency. To make marketers and manages understand the potential advantages that AI could bring, future research could systematically review the factors that impede a firm's AI adoption, and how human intelligence (HI and AI work synergistically to improve a firm's marketing activities and its performance.

\section{ACKNOWLEDGMENT}

Open Access Funding for this article has been covered by the authors of this manuscript. 


\section{REFERENCE}

Abernethy, J., Evgeniou, T., Toubia, O., \& Vert, J. P. (2007). Eliciting consumer preferences using robust adaptive choice questionnaires. IEEE Transactions on Knowledge and Data Engineering, 20(2), 145-155. doi:10.1109/ TKDE.2007.190632

André, Q., Carmon, Z., Wertenbroch, K., Crum, A., Frank, D., Goldstein, W., Huber, J., van Boven, L., Weber, B., \& Yang, H. (2018). Consumer choice and autonomy in the age of artificial intelligence and big data. Customer Needs and Solutions, 5(1), 28-37. doi:10.1007/s40547-017-0085-8

Appio, F. P., Martini, A., Massa, S., \& Testa, S. (2017). Collaborative network of firms: Antecedents and stateof-the-art properties. International Journal of Production Research, 55(7), 2121-2134. doi:10.1080/0020754 3.2016.1262083

Asgari, N., Nikbakhsh, E., Hill, A., \& Farahani, R. Z. (2016). Supply chain management 1982-2015: A review. IMA Journal of Management Mathematics, 27(3), 353-379. doi:10.1093/imaman/dpw004

Balakrishnan, P. V., Gupta, R., \& Jacob, V. S. (2004). Development of hybrid genetic algorithms for product line designs. IEEE Transactions on Systems, Man, and Cybernetics. Part B, Cybernetics, 34(1), 468-483. doi:10.1109/ TSMCB.2003.817051 PMID:15372718

Balducci, B., \& Marinova, D. (2018). Unstructured data in marketing. Journal of the Academy of Marketing Science, 46(4), 557-590. doi:10.1007/s11747-018-0581-x

Bohanec, M., Borštnar, M. K., \& Robnik-Šikonja, M. (2017). Estimation of minimum sample size for identication of the most important features: a case study providing a qualitative B2B sales data set. Croatian Operational Research Review, 515-524.

Bohanec, M., Borštnar, M. K., \& Robnik-Šikonja, M. (2017). Explaining machine learning models in sales predictions. Expert Systems with Applications, 71, 416-428. doi:10.1016/j.eswa.2016.11.010

Bohanec, M., Kljajić Borštnar, M., \& Robnik-Šikonja, M. (2018). Number of Instances for Reliable Feature Ranking in a Given Problem. Business Systems Research: International journal of the Society for Advancing Innovation and Research in Economy, 9(2), 35-44.

Bohanec, M., Robnik-Šikonja, M., \& Borštnar, M. K. (2017). Decision-making framework with double-loop learning through interpretable black-box machine learning models. Industrial Management \& Data Systems, 117(7), 1389-1406. doi:10.1108/IMDS-09-2016-0409

Bohanec, M., Robnik-Šikonja, M., \& Borštnar, M. K. (2017). Organizational learning supported by machine learning models coupled with general explanation methods: A Case of B2B sales forecasting. Organizacija, 50(3), 217-233. doi:10.1515/orga-2017-0020

Bonilla, C. A., Merigó, J. M., \& Torres-Abad, C. (2015). Economics in Latin America: A bibliometric analysis. Scientometrics, 105(2), 1239-1252. doi:10.1007/s11192-015-1747-7

Bose, I., \& Mahapatra, R. K. (2001). Business data mining-A machine learning perspective. Information \& Management, 39(3), 211-225. doi:10.1016/S0378-7206(01)00091-X

Casillas, J., \& Martínez-López, F. J. (2009). Mining uncertain data with multiobjective genetic fuzzy systems to be applied in consumer behaviour modelling. Expert Systems with Applications, 36(2), 1645-1659. doi:10.1016/j. eswa.2007.11.035

Celli, F., Massani, P. Z., \& Lepri, B. (2017, October). Profilio: Psychometric profiling to boost social media advertising. In Proceedings of the 25th ACM international conference on Multimedia (pp. 546-550). doi:10.1145/3123266.3129311

Chang, P. C., Wang, Y. W., \& Tsai, C. Y. (2005). Evolving neural network for printed circuit board sales forecasting. Expert Systems with Applications, 29(1), 83-92. doi:10.1016/j.eswa.2005.01.012

Cui, D., \& Curry, D. (2005). Prediction in marketing using the support vector machine. Marketing Science, 24(4), 595-615. doi:10.1287/mksc.1050.0123

Cui, G., Wong, M. L., \& Lui, H. K. (2006). Machine learning for direct marketing response models: Bayesian networks with evolutionary programming. Management Science, 52(4), 597-612. doi:10.1287/mnsc.1060.0514 
Davenport, T., Guha, A., Grewal, D., \& Bressgott, T. (2020). How artificial intelligence will change the future of marketing. Journal of the Academy of Marketing Science, 48(1), 24-42. doi:10.1007/s11747-019-00696-0

Doğan, İ. (2018). The application of artificial intelligence in new age of marketing: An analysis on ai mobile banking apps (Master's thesis). Sosyal Bilimler Enstitüsü.

Donthu, N., Kumar, S., \& Pattnaik, D. (2020). Forty-five years of journal of business research: A bibliometric analysis. Journal of Business Research, 109, 1-14. doi:10.1016/j.jbusres.2019.10.039

Elo, S., \& Kyngäs, H. (2008). The qualitative content analysis process. Journal of Advanced Nursing, 62(1), 107-115. doi:10.1111/j.1365-2648.2007.04569.x PMID:18352969

Evgeniou, T., Pontil, M., \& Toubia, O. (2007). A convex optimization approach to modeling consumer heterogeneity in conjoint estimation. Marketing Science, 26(6), 805-818. doi:10.1287/mksc.1070.0291

Fethi, M. D., \& Pasiouras, F. (2010). Assessing bank efficiency and performance with operational research and artificial intelligence techniques: A survey. European Journal of Operational Research, 204(2), 189-198. doi:10.1016/j.ejor.2009.08.003

Ghose, A., Ipeirotis, P. G., \& Li, B. (2012). Designing ranking systems for hotels on travel search engines by mining user-generated and crowdsourced content. Marketing Science, 31(3), 493-520. doi:10.1287/mksc.1110.0700

Grewal, D., Roggeveen, A. L., \& Nordfält, J. (2017). The future of retailing. Journal of Retailing, 93(1), 1-6. doi:10.1016/j.jretai.2016.12.008

Hennig-Thurau, T., Wiertz, C., \& Feldhaus, F. (2015). Does Twitter matter? The impact of microblogging word of mouth on consumers' adoption of new movies. Journal of the Academy of Marketing Science, 43(3), 375-394. doi:10.1007/s11747-014-0388-3

Huang, M. H., \& Rust, R. T. (2017). Technology-driven service strategy. Journal of the Academy of Marketing Science, 45(6), 906-924. doi:10.1007/s11747-017-0545-6

Huang, M. H., \& Rust, R. T. (2018). Artificial intelligence in service. Journal of Service Research, 21(2), 155-172. doi:10.1177/1094670517752459

Hummon, N. P., \& Dereian, P. (1989). Connectivity in a citation network: The development of DNA theory. Social Networks, 11(1), 39-63. doi:10.1016/0378-8733(89)90017-8

Ikeda, K., Hattori, G., Ono, C., Asoh, H., \& Higashino, T. (2013). Twitter user profiling based on text and community mining for market analysis. Knowledge-Based Systems, 51, 35-47. doi:10.1016/j.knosys.2013.06.020

Jarek, K., \& Mazurek, G. (2019). Marketing and artificial intelligence. Central European Business Review, 8(2).

Johnson, M. S. (2006). A bibliometric review of the contribution of attribution theory to sales management. Journal of Personal Selling \& Sales Management, 26(2), 181-195. doi:10.2753/PSS0885-3134260205

Kaplan, A., \& Haenlein, M. (2019). Siri, Siri, in my hand: Who's the fairest in the land? On the interpretations, illustrations, and implications of artificial intelligence. Business Horizons, 62(1), 15-25. doi:10.1016/j. bushor.2018.08.004

Kim, J., \& McMillan, S. J. (2008). Evaluation of internet advertising research: A bibliometric analysis of citations from key sources. Journal of Advertising, 37(1), 99-112. doi:10.2753/JOA0091-3367370108

Kose, U., \& Sert, S. (2017). Improving content marketing processes with the approaches by artificial intelligence. arXiv preprint arXiv:1704.02114.

Kumar, V., Dixit, A., Javalgi, R. R. G., \& Dass, M. (2016). Research framework, strategies, and applications of intelligent agent technologies (IATs) in marketing. Journal of the Academy of Marketing Science, 44(1), 24-45. doi:10.1007/s11747-015-0426-9

Kwok, L., \& Yu, B. (2013). Spreading social media messages on Facebook: An analysis of restaurant businessto-consumer communications. Cornell Hospitality Quarterly, 54(1), 84-94. doi:10.1177/1938965512458360

Lee, D., Hosanagar, K., \& Nair, H. S. (2018). Advertising content and consumer engagement on social media: Evidence from Facebook. Management Science, 64(11), 5105-5131. doi:10.1287/mnsc.2017.2902 
Leminen, S., Rajahonka, M., Westerlund, M., \& Wendelin, R. (2018). The future of the Internet of Things: Toward heterarchical ecosystems and service business models. Journal of Business and Industrial Marketing, 33(6), 749-767. doi:10.1108/JBIM-10-2015-0206

Leone, D., Schiavone, F., Appio, F. P., \& Chiao, B. (2021). How does artificial intelligence enable and enhance value co-creation in industrial markets? An exploratory case study in the healthcare ecosystem. Journal of Business Research, 129, 849-859. doi:10.1016/j.jbusres.2020.11.008

Li, B. H., Hou, B. C., Yu, W. T., Lu, X. B., \& Yang, C. W. (2017). Applications of artificial intelligence in intelligent manufacturing: A review. Frontiers of Information Technology \& Electronic Engineering, 18(1), 86-96. doi:10.1631/FITEE.1601885

Li, G., Law, R., Rong, J., \& Vu, H. Q. (2010). Incorporating both positive and negative association rules into the analysis of outbound tourism in Hong Kong. Journal of Travel \& Tourism Marketing, 27(8), 812-828. doi :10.1080/10548408.2010.527248

Lin, W. C., Ke, S. W., \& Tsai, C. F. (2017). Top 10 data mining techniques in business applications: A brief survey. Kybernetes, 46(7), 1158-1170. doi:10.1108/K-10-2016-0302

Liu, J. S., \& Lu, L. Y. (2012). An integrated approach for main path analysis: Development of the Hirsch index as an example. Journal of the American Society for Information Science and Technology, 63(3), 528-542. doi:10.1002/asi.21692

Marinchak, C. L. M., Forrest, E., \& Hoanca, B. (2018). The impact of artificial intelligence and virtual personal assistants on marketing. In Encyclopedia of Information Science and Technology (4th ed., pp. 5748-5756). IGI Global.

Martínez-López, F. J., \& Casillas, J. (2009). Marketing Intelligent Systems for consumer behaviour modelling by a descriptive induction approach based on Genetic Fuzzy Systems. Industrial Marketing Management, 38(7), 714-731. doi:10.1016/j.indmarman.2008.02.003

Marwala, T., \& Hurwitz, E. (2017). Artificial intelligence and economic theory: skynet in the market (Vol. 1). Springer International Publishing. doi:10.1007/978-3-319-66104-9

Matz, S. C., Kosinski, M., Nave, G., \& Stillwell, D. J. (2017). Psychological targeting as an effective approach to digital mass persuasion. Proceedings of the National Academy of Sciences of the United States of America, 114(48), 12714-12719. doi:10.1073/pnas.1710966114 PMID:29133409

McCarthy, J., Minsky, M. L., Rochester, N., \& Shannon, C. E. (1955). Proposalfor the 1956 Dartmouth Summer Research Project on Artificial Intelligence. Dartmouth College.

Mele, C., Spena, T. R., \& Peschiera, S. (2018). Value creation and cognitive technologies: Opportunities and challenges. Journal of Creating Value, 4(2), 182-195. doi:10.1177/2394964318809152

Miah, S. J., Gammack, J., \& Hasan, N. (2017). Extending the framework for mobile health information systems Research: A content analysis. Information Systems, 69, 1-24. doi:10.1016/j.is.2017.04.001

Miralles-Pechuán, L., Rosso, D., Jiménez, F., \& García, J. M. (2017). A methodology based on Deep Learning for advert value calculation in CPM, CPC and CPA networks. Soft Computing, 21(3), 651-665. doi:10.1007/ s00500-016-2468-4

Mitić, V. (2019). Benefits of artificial intelligence and machine learning in marketing. In Sinteza 2019-International Scientific Conference on Information Technology and Data Related Research (pp. 472-477). Singidunum University.

Mustak, M., Salminen, J., Plé, L., \& Wirtz, J. (2021). Artificial intelligence in marketing: Topic modeling, scientometric analysis, and research agenda. Journal of Business Research, 124, 389-404. doi:10.1016/j. jbusres.2020.10.044

Orriols-Puig, A., Martínez-López, F. J., Casillas, J., \& Lee, N. (2013). Unsupervised KDD to creatively support managers' decision making with fuzzy association rules: A distribution channel application. Industrial Marketing Management, 42(4), 532-543. doi:10.1016/j.indmarman.2013.03.005 
Orriols-Puig, A., Martínez-López, F. J., Casillas, J., \& Lee, N. (2013). Unsupervised KDD to creatively support managers' decision making with fuzzy association rules: A distribution channel application. Industrial Marketing Management, 42(4), 532-543. doi:10.1016/j.indmarman.2013.03.005

Paschen, U., Pitt, C., \& Kietzmann, J. (2020). Artificial intelligence: Building blocks and an innovation typology. Business Horizons, 63(2), 147-155. doi:10.1016/j.bushor.2019.10.004

Poria, S., Gelbukh, A., Cambria, E., Hussain, A., \& Huang, G. B. (2014). EmoSenticSpace: A novel framework for affective common-sense reasoning. Knowledge-Based Systems, 69, 108-123. doi:10.1016/j.knosys.2014.06.011

Rong, J., Vu, H. Q., Law, R., \& Li, G. (2012). A behavioral analysis of web sharers and browsers in Hong Kong using targeted association rule mining. Tourism Management, 33(4), 731-740. doi:10.1016/j.tourman.2011.08.006

Rui, H., Liu, Y., \& Whinston, A. (2013). Whose and what chatter matters? The effect of tweets on movie sales. Decision Support Systems, 55(4), 863-870. doi:10.1016/j.dss.2012.12.022

Rutz, O. J., \& Watson, G. F. IV. (2019). Endogeneity and marketing strategy research: An overview. Journal of the Academy of Marketing Science, 47(3), 479-498. doi:10.1007/s11747-019-00630-4

Sánchez, L., Couso, I., \& Casillas, J. (2009). Genetic learning of fuzzy rules based on low quality data. Fuzzy Sets and Systems, 160(17), 2524-2552. doi:10.1016/j.fss.2009.03.004

Scott, W. R. (1987). The adolescence of institutional theory. Administrative Science Quarterly, 32(4), $493-511$. doi: $10.2307 / 2392880$

Shin, H., \& Cho, S. (2006). Response modeling with support vector machines. Expert Systems with Applications, 30(4), 746-760. doi:10.1016/j.eswa.2005.07.037

Siau, K., \& Yang, Y. (2017, May). Impact of artificial intelligence, robotics, and machine learning on sales and marketing. In Twelve Annual Midwest Association for Information Systems Conference (MWAIS 2017) (pp. 18-19). Academic Press.

Stahl, B. C., Andreou, A., Brey, P., Hatzakis, T., Kirichenko, A., Macnish, K., Laulhé Shaelou, S., Patel, A., Ryan, M., \& Wright, D. (2021). Artificial intelligence for human flourishing-Beyond principles for machine learning. Journal of Business Research, 124, 374-388. doi:10.1016/j.jbusres.2020.11.030

Stangor, C. (2015). Social groups in action and interaction. Routledge. doi:10.4324/9781315677163

Strozzi, F., Colicchia, C., Creazza, A., \& Noè, C. (2017). Literature review on the 'Smart Factory' concept using bibliometric tools. International Journal of Production Research, 55(22), 6572-6591. doi:10.1080/00207543 .2017 .1326643

Thomaz, F., Salge, C., Karahanna, E., \& Hulland, J. (2020). Learning from the Dark Web: Leveraging conversational agents in the era of hyper-privacy to enhance marketing. Journal of the Academy of Marketing Science, 48(1), 43-63. doi:10.1007/s11747-019-00704-3

Tornatzky, L., \& Fleischer, M. (1990). The process of technology innovation. Lexington Books.

Vlačić, B., Corbo, L., Silva, S. C., \& Dabić, M. (2021). The evolving role of artificial intelligence in marketing: A review and research agenda. Journal of Business Research, 128, 187-203. doi:10.1016/j.jbusres.2021.01.055

Vogel, R., \& Güttel, W. H. (2013). The dynamic capability view in strategic management: A bibliometric review. International Journal of Management Reviews, 15(4), 426-446.

Wernerfelt, B. (1984). A resource-based view of the firm. Strategic Management Journal, 5(2), 171-180. doi:10.1002/smj.4250050207

Wirth, N. (2018). Hello marketing, what can artificial intelligence help you with? International Journal of Market Research, 60(5), 435-438. doi:10.1177/1470785318776841

Yang, Y., \& Siau, K. (2018). A qualitative research on marketing and sales in the artificial intelligence age. Midwest United States Association for Information Systems (MWAIS) 2018 Proceedings.

Zhang, C., \& Huang, Z. (2015). Mining tourist motive for marketing development via twice-learning. Applied Artificial Intelligence, 29(2), 119-133. doi:10.1080/08839514.2015.993554 
Zhang, C., Huang, Z., Cao, F., \& Chen, X. (2019). Recognise me from outside to inside: Learning the influence chain of urban destination personalities. Tourism Management, 70, 390-403. doi:10.1016/j.tourman.2018.09.005

Zhang, C., Kwon, Y. P., Kramer, J., Kim, E., \& Agogino, A. M. (2017). Concept clustering in design teams: A comparison of human and machine clustering. Journal of Mechanical Design, 139(11), 111414. doi:10.1115/1.4037478

Zhang, C., \& Zhang, J. (2014). Analysing Chinese citizens' intentions of outbound travel: A machine learning approach. Current Issues in Tourism, 17(7), 592-609. doi:10.1080/13683500.2013.768606

Zhong, S., Geng, Y., Liu, W., Gao, C., \& Chen, W. (2016). A bibliometric review on natural resource accounting during 1995-2014. Journal of Cleaner Production, 139, 122-132. doi:10.1016/j.jclepro.2016.08.039

Živković, M. (2019). Integration of Artificial Intelligence with Cloud Services. In Sinteza 2019-International Scientific Conference on Information Technology and Data Related Research (pp. 381-387). Singidunum University.

Jing Chen is an assistant professor of marketing at Texas A\&M University Kingsville, her research areas are artificial intelligence in marketing, marketing strategy, and so on.

Jose Humberto Ablanedo Rosas is Associate Professor of Operations and Supply Chain Management at the College of Business Administration, University of Texas at El Paso. He currently holds the Professorship in Western Hemisphere Trade Research II. He has collaborated with researchers from different universities around the world. His research has been published in well-known academic journals such as Computers \& Industrial Engineering, Computers and Operations Research, European Journal of Operational Research, Expert Systems, International Journal of Production Research, International Journal of Project Management, and OMEGA, among others.

Gary L. Frankwick (Ph.D., Arizona State University) is Professor and Marcus Hunt Chair in International Business in the department of Marketing and Management. Dr. Frankwick's research and teaching interests include marketing strategy, sales, business-to-business marketing, International business, and new product development.

Fernando R. Jiménez's (Ph.D. in Marketing from Oklahoma State University) research interests include branding, cross-cultural marketing, and research methodology. He enjoys teaching doctoral, MBA, and undergraduate marketing courses. 